\title{
Orchids of Mongolia: Taxonomy, Species Richness and
} Conservation Status

\author{
Shukherdorj Baasanmunkh ${ }^{1} \mathbb{D}$, Batlai Oyuntsetseg ${ }^{2}$, Petr Efimov ${ }^{3}$, Zagarjav Tsegmed ${ }^{4}$, Sumiya Vandandorj ${ }^{5}{ }^{(D)}$, \\ Khurelpurev Oyundelger 6,7 (D), Magsar Urgamal 4, Altangerel Undruul ${ }^{2}$, Khurelbaatar Khaliunaa ${ }^{2}$, \\ Tugsuu Namuulin ${ }^{8}$ and Hyeok Jae Choi ${ }^{1, *(D)}$
}

Citation: Baasanmunkh, S.; Oyuntsetseg, B.; Efimov, P.; Tsegmed, Z.; Vandandorj, S.; Oyundelger, K.; Urgamal, M.; Undruul, A.; Khaliunaa, K.; Namuulin, T.; et al. Orchids of Mongolia: Taxonomy, Species Richness and Conservation Status. Diversity 2021, 13, 302.

https://doi.org/10.3390/d13070302

Academic Editors: Miguel Ferrer and Adriano Stinca

Received: 31 May 2021

Accepted: 30 June 2021

Published: 2 July 2021

Publisher's Note: MDPI stays neutral with regard to jurisdictional claims in published maps and institutional affiliations.

Copyright: (c) 2021 by the authors. Licensee MDPI, Basel, Switzerland. This article is an open access article distributed under the terms and conditions of the Creative Commons Attribution (CC BY) license (https:// creativecommons.org/licenses/by/ $4.0 /)$.
1 Department of Biology and Chemistry, Changwon National University, Changwon 51140, Korea; baasanmunkh.sh@gmail.com

2 Department of Biology, School of Arts and Science, National University of Mongolia, Ulaanbaatar 14201, Mongolia; oyunaa@num.edu.mn (B.O.); undruula@yahoo.com (A.U.); khurelbaatar.khaliunaa@gmail.com (K.K.)

3 Komarov Botanical Institute of the Russia Academy of Sciences, 197376 Saint-Petersburg, Russia; efimov81@mail.ru

4 Laboratory of Flora and Plant Systematics, Botanic Garden and Research Institute, Mongolian Academy of Sciences, Ulaanbaatar 13330, Mongolia; tsegmidzagarjaw@gmail.com (Z.T.); urgamalm@mas.ac.mn (M.U.)

5 Wildlife Science and Conservation Center of Mongolia, Ulaanbaatar 14210, Mongolia; vandandorj@wscc.org.mn

6 Chair of Biodiversity of Higher Plants, International Institute (IHI) Zittau, Technical University Dresden, Markt 23, D-02763 Zittau, Germany; oyundelger.khurelpurev@senckenberg.de

7 Department of Botany, Senckenberg Museum of Natural History Görlitz, D-02826 Görlitz, Germany

8 Hustai National Park Trust, Ulaanbaatar 16050, Mongolia; namuulintugs@gmail.com

* Correspondence: hjchoi1975@changwon.ac.kr; Tel.: +82-55-213-3475

Abstract: Orchidaceae is a diverse, globally important plant family with high conservation assessment and prioritization requirements. The checklist of Orchidaceae in Mongolia was updated based on herbarium materials, literature, and field observations. Mongolian orchids were revised as comprising 26 taxa belonging to 14 genera with major updates were conducted on Herminium and Epipactis. In particular, H. alaschanicum, previously noted in the Alashan Gobi region, was added to the flora of Mongolia based on literature and type specimens. Epipactis helleborine and E. palustris were excluded from the Mongolian flora owing to the absence of herbarium specimens and wild collection from Mongolia. Assessment of all orchid species at the national level resulted in 1, 4, 7, 11, and 2 species as critically endangered (CR), endangered (EN), vulnerable (VU), near threatened (NT), and data deficient (DD), respectively, according to IUCN criteria. Species richness and conservation gap analyses of 970 georeferenced orchid records based on $0.5^{\circ} \times 0.5^{\circ}$ grid cells across 16 phytogeographical regions of Mongolia, showed that four phytogeographical regions, Khangai, Khuvgul, Khentii and Mongolian Dauria, have a high number of orchids. Regrettably, most orchid-rich locations in Mongolia are not fully within protected areas, highlighting the need for protection management updates. Based on herbarium collections, we prepared grid distribution maps of the 26 taxa using $40 \times 40 \mathrm{~km}^{2}$ grids. Photographs of 18 taxa taken during fieldwork were included, providing valuable information on species morphology and typical habitat.

Keywords: Orchidaceae; distribution pattern; flora of Mongolia; orchid-hotspot; protected area

\section{Introduction}

Orchidaceae is a diverse, globally important plant family with an urgent need for conservation assessment and prioritization [1-3]. The orchid family comprises approximately 30,300 species and is one of the largest and most widespread families of flowering plants worldwide $[4,5]$. Unfortunately, many orchid species are becoming extinct and 
threatened owing to destruction of their habitats, use in traditional medicine, illegal trade, and climate change [3-6]. There are only ca. 600 orchid species listed as threatened on the global database of threatened species according to the International Union for the Conservation of Nature (IUCN) [6]. Additionally, Zizka et al. [2] provided an automated conservation assessment of the orchids including 13,910 species, of which 4340 species are possibly threatened worldwide. Moreover, there are numerous publications on regional assessments of orchid species using IUCN categories and criteria [7-10]. For example, the lady's slipper orchid (Cypripedium calceolus L.) is classified of least concern on a global scale [11], whereas as endangered or vulnerable in many European and Asian countries on a national scale $[8,9,11-14]$.

Several researchers have studied the species richness patterns of orchids in relation to the impact of climate change, and their conservation status on a regional or global scale [15-21]. For example, Huang et al. [15], revealed the hotspots and species richness of Orchidaceae in China, including 1449 species, of which 97\% were included in protected areas. In addition, Liu et al. [10] assessed 1582 orchid taxa (of which $42.5 \%$ were threatened) for regional and global categories in China. Efimov [17] published a checklist of 135 orchid species in Russia, with a distribution pattern based on administrative regions. Moreover, Khapugin [22] summarized the global orchid distribution within protected areas based on published data, with the exception of Mongolia, owing to the lack of information. Hence, we aimed to fill this gap based on the revision of comprehensive herbariums and literature, as well as field observation data.

The species diversity of Orchidaceae in Mongolia is not particularly rich, with 27 taxa belonging to 15 genera reported [23-26]. Moreover, there are no endemic orchid species noted [27]; however, most of the species are considered as rare and threatened at the national level because of their restricted distribution, habitat disturbance (forest cutting, mining), and impact of climate change in Mongolia [9,26,28,29]. In general, orchids are distributed mainly in the northern, eastern, and central parts of Mongolia [23-26,30]. Northern Mongolia is the southern boundary of the Siberian boreal forest, and two large mountain systems, Khangai and Khentii stretch from the central part to the northeast of Mongolia, where the majority of forests and forest steppes are located [23]. Such forest habitats with an optimum edaphic environment facilitate orchid species' growth compared to the dry steppes and deserts in southern and south-eastern Mongolia. The first taxonomic key, growing habitats, and regional distribution of Orchidaceae in Mongolia was provided by Grubov [23], and comprised 21 species. Since 1982, most studies have focused on the national conservation status and regional distribution range [9,28,29]. More recently, some genera, such as Herminium L., Spiranthes Rich., and Platanthera Rich. have been revised based on morphological and molecular evidence from Asian countries, including Mongolia [31-33]. Our previous study reported Cypripeidum Sw. with a photo illustration, its habitat, species examination, and a detailed distribution map of the country [26]. However, none of the above mentioned studies have employed quantitative approaches to assess species richness and to identify the conservation gap for orchids in Mongolia, owing to limited data collection and field observations. Hence, orchid revisions with an updated checklist, richness pattern, and detailed distribution map would be a valuable contribution to conservation management and its efforts in Mongolia.

The objectives of the present study were (i) to update the checklist and distribution map, (ii) to identify areas with high orchid species richness, and (iii) to assess all species in Mongolia using IUCN categories and criteria.

\section{Materials and Methods}

Data were obtained from three main sources: (i) herbarium collections from ALTB, GFW, HAL, K, LE, MW, NS, NSK, OSBU, TK, UBA and UBU (acronyms according to Thiers [34]), and the Virtual Guide to the Flora of Mongolia [35]; (ii) literature, and (iii) field survey observations between 2015 and 2020. In addition, several species observations were gathered from the iNaturalist platform under the "Flora of Mongolia" project 
(https: / / www.inaturalist.org/projects / flora-of-mongolia?tab=observations, accessed on 15 March 2021). Most of the orchid species were photographed during our field surveys, and herbarium specimens were deposited in the herbarium of the National University of Mongolia.

Taxonomic identification was based on Grubov [23,36], and recently published articles on genera Herminium [31], followed by Spiranthes [32], Platanthera [33], and Dactylorhiza [37]. The nomenclature of each taxon was followed based on the Plants of the World Online (http: / / www.plantsoftheworldonline.org/, accessed on 10 April 2021), International Plant Name Index (www.ipni.org, accessed on 10 April 2021), and The Plant List (www.theplantlist.org, accessed on 15 April 2021).

The assessments were based on IUCN criterion B (including sub-criteria B1; the extent of occurrence, EOO, and B2; the area of occupancy, AOO) which uses geographic range size and evidence of declining or fragmented populations [38]. Criterion B is suitable for estimating conservation status even when data are limited and the distribution of a taxon is only known from a few georeferenced records [38]. The EOO and AOO were estimated using the package ConR [39] in R 4.0.3. [40]. The minimum AOO was estimated based on a user-defined grid cell of $2 \mathrm{~km}^{2}$, as recommended by the IUCN [38].

We created a grid net for Mongolia with a spatial resolution of $0.5^{\circ} \times 0.5^{\circ}$ grid size (approximately $50 \times 50 \mathrm{~km}^{2}$ ) using the Fishnet tool in ArcGIS 10.3 [41]. The country was divided into 715 grid cells. The species richness map was constructed by calculating the total number of species within each cell based on the grid net and species distribution data. The same approach was applied to create a species richness map of the 16 phytogeographical regions defined by Grubov [23]. Additionally, we used geographic information system data of protected areas (downloaded from the World Database on Protected Area (WDPA), https: / / protectedplanet.net/, accessed on 20 March 2021) to determine the extent to which species were included in the protected areas. We excluded nature monuments, which are a category of protected areas in Mongolia, as they usually cover small areas and are primarily dedicated to the preservation of historical and cultural heritage.

The point distribution map of each taxon was based on a $40 \times 40 \mathrm{~km}^{2}$ grid cell size in Mongolia. The distribution points, marked by three different symbols, are summarized in Table 1.

Table 1. Mapping symbols used in the distribution maps.

\begin{tabular}{ccc}
\hline Symbols & Description & Brief Explanation \\
\hline$\bullet$ & Before 2000 & After 2000 \\
\hline & All other & $\begin{array}{c}\text { All dots indicate herbarium collections } \\
\text { Based on other sources: literature and } \\
\text { observations from iNaturalist }\end{array}$ \\
\hline
\end{tabular}

\section{Results}

\subsection{Checklist and Threatened Status}

The updated checklist of Orchidaceae is represented by 26 taxa (including 24 species, 1 subspecies, and 1 nothospecies) from 14 genera in Mongolia (Table 2). Among them, Dactylorhiza (six taxa), Cypripedium (four taxa) and Platanthera (three taxa) were the most species-rich genera in Mongolia. All species were assessed for their regional conservation status: one species (Calypso bulbosa) was evaluated as critically endangered, four species (Dactylorhiza fuchsii, Orchis militaris, Neottia camtschatea and N. puberula) as endangered, and seven species as vulnerable. The remaining 13 taxa (11 and two) were classified as near threatened and data deficient, respectively (Table 2). Only Cypripedium $\times$ ventricosum was not assessed in this study because of its hybrid nature. Photographs with detailed parts of the representatives of 18 taxa are shown in Figures 1-3.

We prepared the grid distribution maps of the 26 taxa, which are available in Appendix A. Based on these results, several species, namely Goodyera repens (Figures 1a and A14), Gymnadenia conopsea (Figures 3a and A15), Corallorhiza trifida (Figures 1b and A2), Herminium monorchis (Figures 1c and A17), Dactylorhiza viridis, (Figures 3c and A12), D. salina 
(Figures 3d and A10), Cypripedium guttatum (Figures 2b and A4), and Spiranthes australis (Figures 1d and A26) were observed to be widely distributed in the northern and central parts of Mongolia. Some species such as Calypso bulbosa (Figure A1), Herminium alaschanicum (Figures $3 \mathrm{~h}$ and A16) and Orchis militaris (Figures $3 \mathrm{~g}$ and A21) occurred only in a few locations in northern, central, and southern Mongolia (Appendix A). Finally, Table 2 summarizes the number of collection records, distribution size of EOO and AOO, conservation status, regional distribution range, and preserved herbaria.

\subsection{Species Richness and Distribution}

We found 26 species of Orchidaceae belonging to 14 genera, in 13 phytogeographical regions of Mongolia (Figure 4a). The Khangai and Mongolian Dauria regions had the highest number of species, with 21 species each, followed by Khuvsgul (18 species), Khentii (16 species), and Foothills of Great Khingan (11 species). No orchids were found in the Trans-Altai Gobi, Gobi Altai, or the East Gobi, and the Alashan Gobi region had one orchid species, Herminium alaschanicum, which was found only in this region. In addition, Dactylorhiza incarnata subsp. cruenta was observed only in the Khangai region, and Neottia puberula was found only in the Foothills of Great Khingan. Four species were observed in only two regions. For instance, Calypso bulbosa was found in the Khentii, Cypripedium ventricosum in the Khuvsgul and Orchis militaris in the Khangai region. Platanthera oligantha was found only in the Khuvsgul and Khangai regions. Dactylorhiza salina, which was found in 12 phytogeographical regions, was the most widely distributed orchid species in Mongolia.

Table 2. The checklist of Orchidaceae in Mongolia with red list assessments, regional distribution, and preserved herbaria.

\begin{tabular}{|c|c|c|c|c|c|c|c|c|}
\hline No. & Accepted Taxon Name & $\begin{array}{c}\text { Number } \\
\text { of Records }\end{array}$ & EOO km² & $\mathrm{AOO} \mathrm{km}{ }^{2}$ & $\begin{array}{l}\text { Threat Category and } \\
\text { Criteria in This Study }\end{array}$ & $\begin{array}{l}\text { Pervious Threat Category and } \\
\text { Criteria with Reference }\end{array}$ & $\begin{array}{c}\text { Phytogeographical } \\
\text { Regions in This Study }\end{array}$ & Preserved Herbaria \\
\hline 1 & Calypso bulbosa (L.) Oakes & 2 & - & 8 & CR B2a & CR B1+B2a,b(iii) [28] & 2,4 & LE, MW \\
\hline 2 & Corallorhiza trifida Châtel. & 37 & 301,097 & 140 & NT & VU D2 [28] & $1,2,4$ & $\begin{array}{l}\text { GFW, HAL, LE, MW, UBA, } \\
\text { UBU }\end{array}$ \\
\hline 3 & Cypripedium calceolus $\mathrm{L}$. & 37 & 69,920 & 128 & NT & VU B2ab(ii,iii) [28] & $1,2,4$ & LE, MW, UBA, UBU \\
\hline 4 & Cypripedium guttatum Sw. & 106 & 522,094 & 404 & NT & VU A4c [28] & $1,2,3,4,5$ & $\begin{array}{l}\text { GFW, HAL, KHU, LE, MW, } \\
\text { UBA UBU }\end{array}$ \\
\hline 5 & Cypripedium macranthos Sw. & 40 & 157,732 & 144 & VU B1a & EN B2ab(ii,iii,iv) [29] & $1,2,4,5$ & LE, MW, NS, UBA, UBU, \\
\hline 6 & Cypripedium $\times$ ventricosum $\mathrm{Sw}$. & 3 & 15,146 & 12 & NA & CR B1b(i,ii, iiii,iv) $[9]$ & 2 & MW, UBU \\
\hline 7 & Dactylorhiza fuchsii (Druce.) Soó & 12 & 12,247 & 36 & EN B2a & CR B1ab(iii,iv)+2ab(iii,iv) [29] & 2,4 & LE, UBA, UBU \\
\hline 8 & Dactylorhiza incarnata (L.) Soó & 12 & 128,431 & 32 & VU B1a+B2a & VU B2ab(ii,iii,iv) [29] & 3,5 & LE, MW, UBU \\
\hline 9 & $\begin{array}{l}\text { Dactylorhiza incarnata subsp. cruenta } \\
\text { (O.F.Mull.) P.D.Sell }\end{array}$ & 1 & - & - & $\mathrm{DD}$ & - & 3 & MW \\
\hline 10 & Dactylorhiza salina (Turcz. ex Lindl.) Soó & 159 & $1,170,647$ & 616 & NT & - & $1-11,14$ & $\begin{array}{l}\text { GFW, HAL, KHU, LE, NS, } \\
\text { NSK, UBA, UBU }\end{array}$ \\
\hline 11 & Dactylorhiza umbrosa (Kar. \& Kir.) Nevski & 14 & 351,909 & 56 & NT & - & $1,3,4,7,10,14$ & LE, MW \\
\hline 12 & $\begin{array}{l}\text { Dactylorhiza viridis (L.) R.M.Bateman, } \\
\text { Pridgeon \& M.W.Chase }\end{array}$ & 82 & 589,844 & 316 & NT & - & $1-7$ & LE, MW, NS, UBA, UBU \\
\hline 13 & Epipogium aphyllum Sw. & 14 & 125,481 & 56 & VU B1a & VU B2ab(i,iii,iii) [28] & $1,2,3,4$ & LE, MW, UBA \\
\hline 14 & Goodyera repens (L.) R.Br. & 58 & 426,394 & 220 & NT & - & $1,2,3,4,6$ & $\begin{array}{l}\text { GFW, HAL, LE, MW, } \\
\text { OSBU, UBA, UBU }\end{array}$ \\
\hline 15 & Gymnadenia conopsea (L.) R.Br. & 126 & 551,578 & 496 & NT & VU B1ab(ii,iii)+B2ab(ii,iii) [29] & $1,2,3,4,5$ & $\begin{array}{l}\text { GFW, HAL, LE, MW, UBA, } \\
\text { UBU }\end{array}$ \\
\hline 16 & Herminium alaschanicum Maxim. & 1 & - & - & DD & - & 16 & $\mathrm{~K}, \mathrm{LE}$ \\
\hline 17 & Herminium monorchis (L.) R.Br. & 62 & 551,976 & 240 & NT & NT [9] & $1-5,8,9,10$ & $\begin{array}{l}\text { GFW, HAL, LE, MW, UBA, } \\
\text { UBU }\end{array}$ \\
\hline 18 & Malaxis monophyllos (L.) Sw. & 60 & 673,163 & 236 & NT & - & $1,2,3,4,5$ & $\begin{array}{l}\text { GFW, HAL, LE, MW, UBA, } \\
\text { UBU }\end{array}$ \\
\hline 19 & Neottia camtschatea (L.) Rchb.f. & 3 & 25,822 & 12 & EN B2a & CR D1 [29] & $1,2,3,7$ & GFW, HAL, MW \\
\hline 20 & Neottia puberula (Maxim.) Szlach. & 3 & 12 & 12 & EN B1a+B2a & - & 5 & MW \\
\hline 21 & Orchis militaris $\mathrm{L}$. & 11 & 2,210 & 16 & EN B1a+B2a & EN B2ab(i,iii,iv) [29] & 3,4 & HAL, LE, MW \\
\hline 22 & Platanthera bifolia (L.) Rich. & 11 & 60,111 & 44 & VU B1a & CR D1 [29] & $1,2,3,4$ & LE, UBA \\
\hline 23 & Platanthera fuscescens (L.) Kraenzl. & 14 & 119,109 & 56 & VU B1a & - & $2,3,4,5$ & LE, MW, UBA \\
\hline 24 & Platanthera oligantha Turcz. & 11 & 30,189 & 44 & VU B1a & - & 1,3 & $\mathrm{LE}, \mathrm{MW}$ \\
\hline 25 & $\begin{array}{l}\text { Ponerorchis cucullata (L.) X.H.Jin, Schuit. } \\
\text { and W.T.Jin }\end{array}$ & 33 & 237,000 & 128 & VU B1a & CR D1 [29] & $1,2,3,4$ & HAL, LE, MW, UBA, UBU \\
\hline 26 & Spiranthes australis (R.Br.) Lindl. & 53 & 623,337 & 208 & NT & - & $2,3,4,5,8,9,10$ & LE, MW, NS, UBA, UBU \\
\hline
\end{tabular}

EOO, extent of occurrence; AOO, area of occupancy; CR, critically endangered; EN, endangered; VU, vulnerable; NT, near threatened; $\mathrm{DD}$, data deficient; NA, not assessed.

Based on the grid map of species richness, 155 cells had one to four orchid species, whereas only 33 cells from among the 715 cells had five or more species. Our results indicated that the area covered by orchids accounted for approximately $26 \%$ of the Mongolian territory. Almost all observations were distributed in the northern part of the country, particularly at latitudes higher than $45^{\circ} \mathrm{N}$ (Figure $4 \mathrm{~b}$ ). If we look closely at the localities with high orchid species richness (Figure 4b), 14 species were recorded within a single grid cell around the Noyon Mountain, along the borders of Mandal soum in Selenge province and Batsumber and Bornuur soums in Tuv province, which was the most orchid-rich area. Two grid cells each recorded the second highest number of species (11 species) observed. 
Both locations were near the Mongolian-Russian border, particularly in the north-eastern part of Khuder soum in Selenge province, and between Dadal soum in Khentii province and Bayan-Uul soum in Dornod province. These were followed by three cells with ten species, two in Selenge province, and one in the southern part of the Darkhad depression in Khuvsgul province. The grid cell with the highest number of orchid species overlapped with the Noyon Mountain nature reserve. However, the nature reserve has a smaller area than the grid cell; thus, not all species in the grid cell are within the protected area. Among the five cells with 10 to 11 species, one cell was partially included within a Strictly Protected Area and two cells were partially included in national parks (Figure 4b).
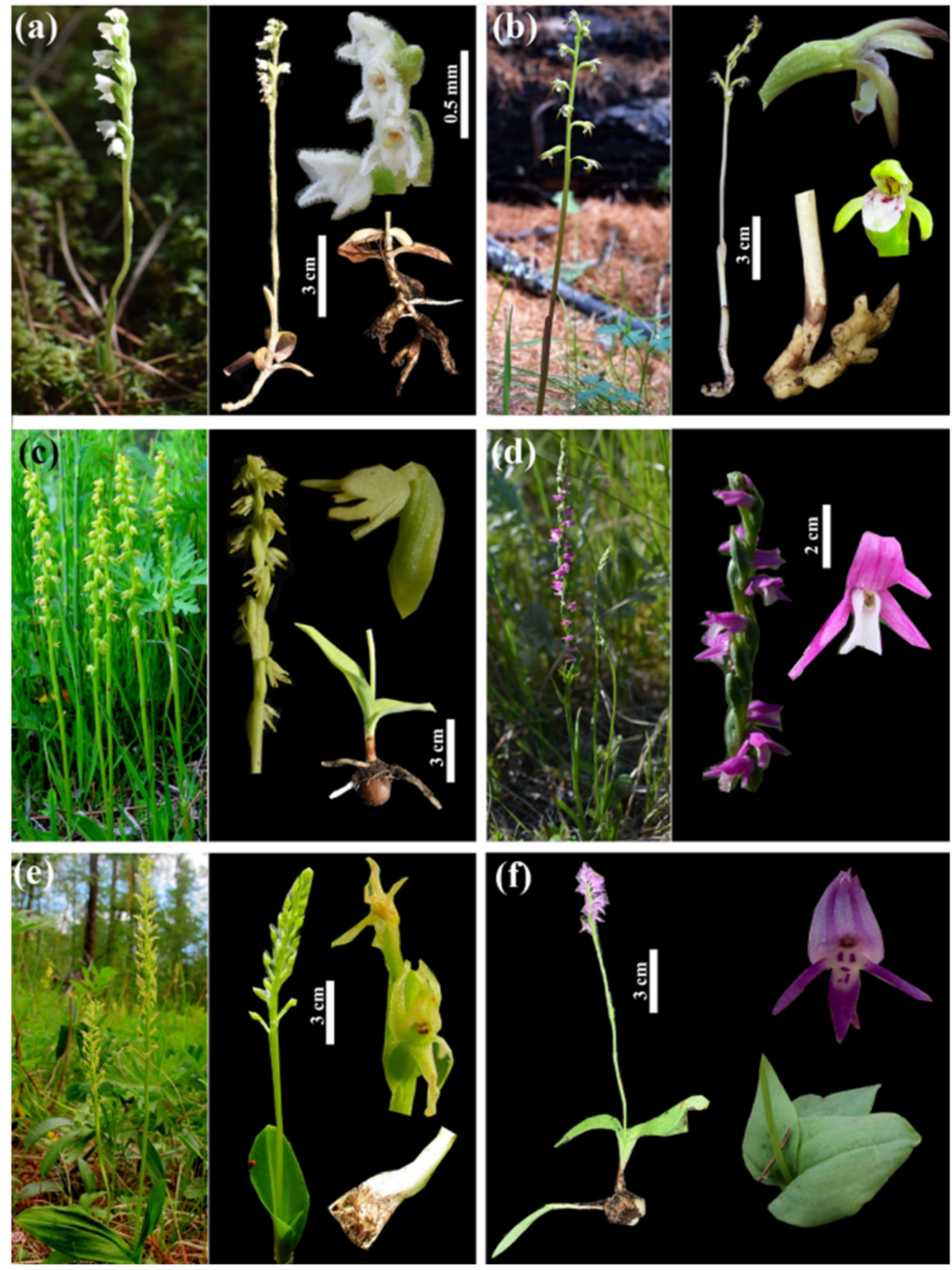

Figure 1. Representative taxa of Orchidaceae in Mongolia: (a) Goodyera repens, (b) Corallorhiza trifida, (c) Herminium monorchis, (d) Spiranthes australis, (e) Malaxis monophyllos, (f) Ponerorchis cucullata. (Photos: (a-c) by Sh. Baasanmunkh; (c-f) by H.J. Choi, T. Namuulin). 

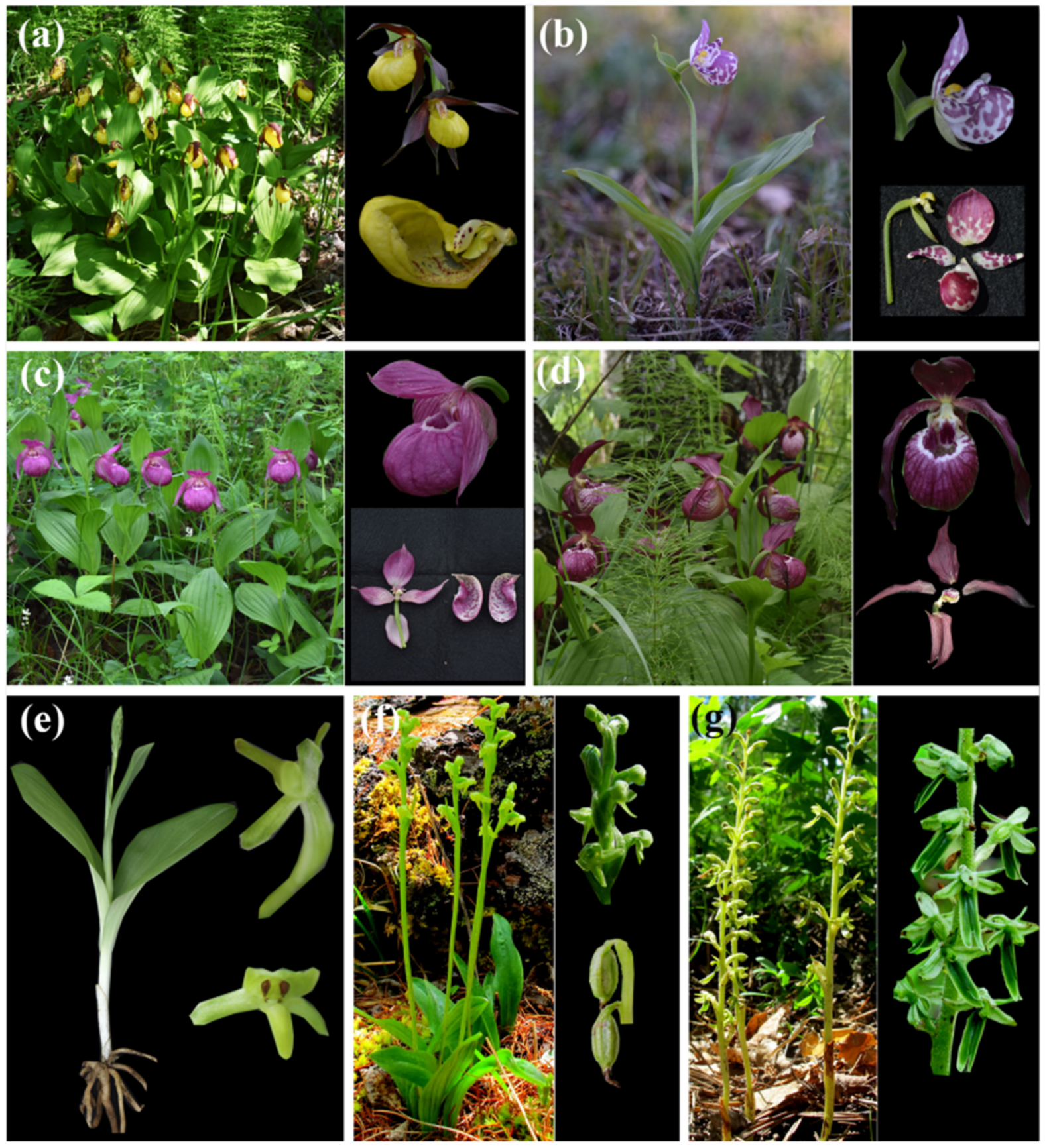

Figure 2. Representative taxa of Orchidaceae in Mongolia: (a) Cypripedium calceolus, (b) Cypripedium guttatum, (c) Cypripedium macranthos, (d) Cypripedium $\times$ ventricosum, (e) Platanthera fuscescens, (f) Platanthera oligantha, (g) Neottia camtschatea (Photos: (a-d) by Sh. Baasanmunkh, (e) by B. Oyuntsetseg and (f,g) by B. Josef).

In terms of protection, 23 out of the 26 orchid species had at least one observation in a protected area of Mongolia (Figure 4b). For instance, the distribution areas of Herminium alaschanicum and Calypso bulbosa were found to be within protected areas, whereas that of Cypripedium $\times$ ventricosum, Dactylorhiza incarnata subsp. cruenta and Neottia camtschatea were not within any protected area, despite all these species having less than three observations each in our database. In addition, two observations of Neottia puberula were found within a protected area, and one observation was noted outside. Corallorhiza trifida and Dactylorhiza fuchsii had more than $50 \%$ of the total observations noted within protected areas, whereas the remaining 18 species had less than $50 \%$ of the total observations included in protected areas. 

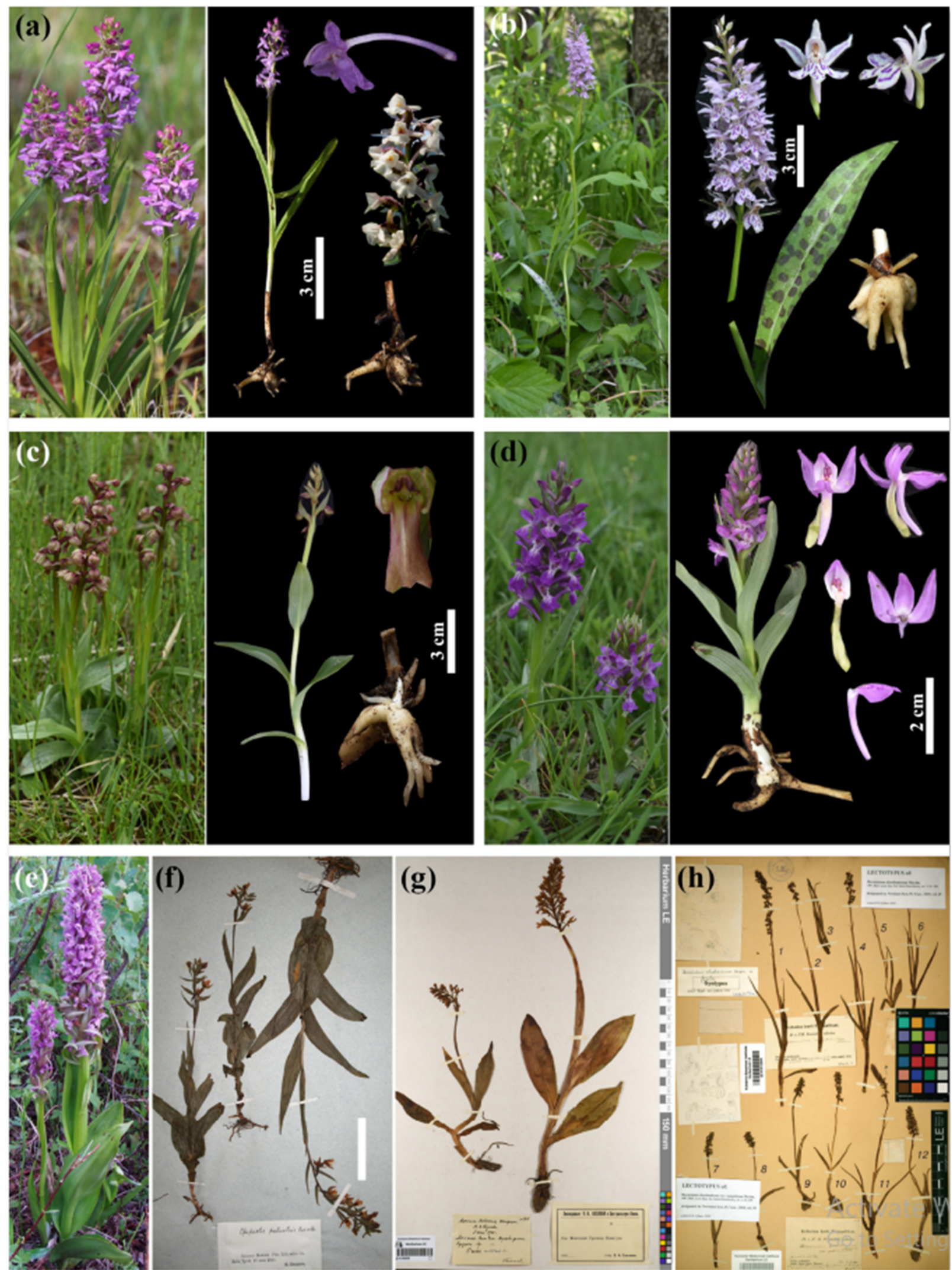

Figure 3. Representative taxa of Orchidaceae in Mongolia: (a) Gymnadenia conopsea, (b) Dactylorhiza fuchsii, (c) D. viridis, (d) D. umbrosa, (e) D. salina, (f) Epipactis palustris, (g) Orchis militaris, (h) Herminium alaschanicum $(1-6,11)$ and H. alaschanicum var. tanguticum $(7-10,12)$ (Photos: (a-d) by Sh. Baasanmunkh, (e) by Ch. Dulamsuren, (f) from T.K. and (g,h) from L.E.). 

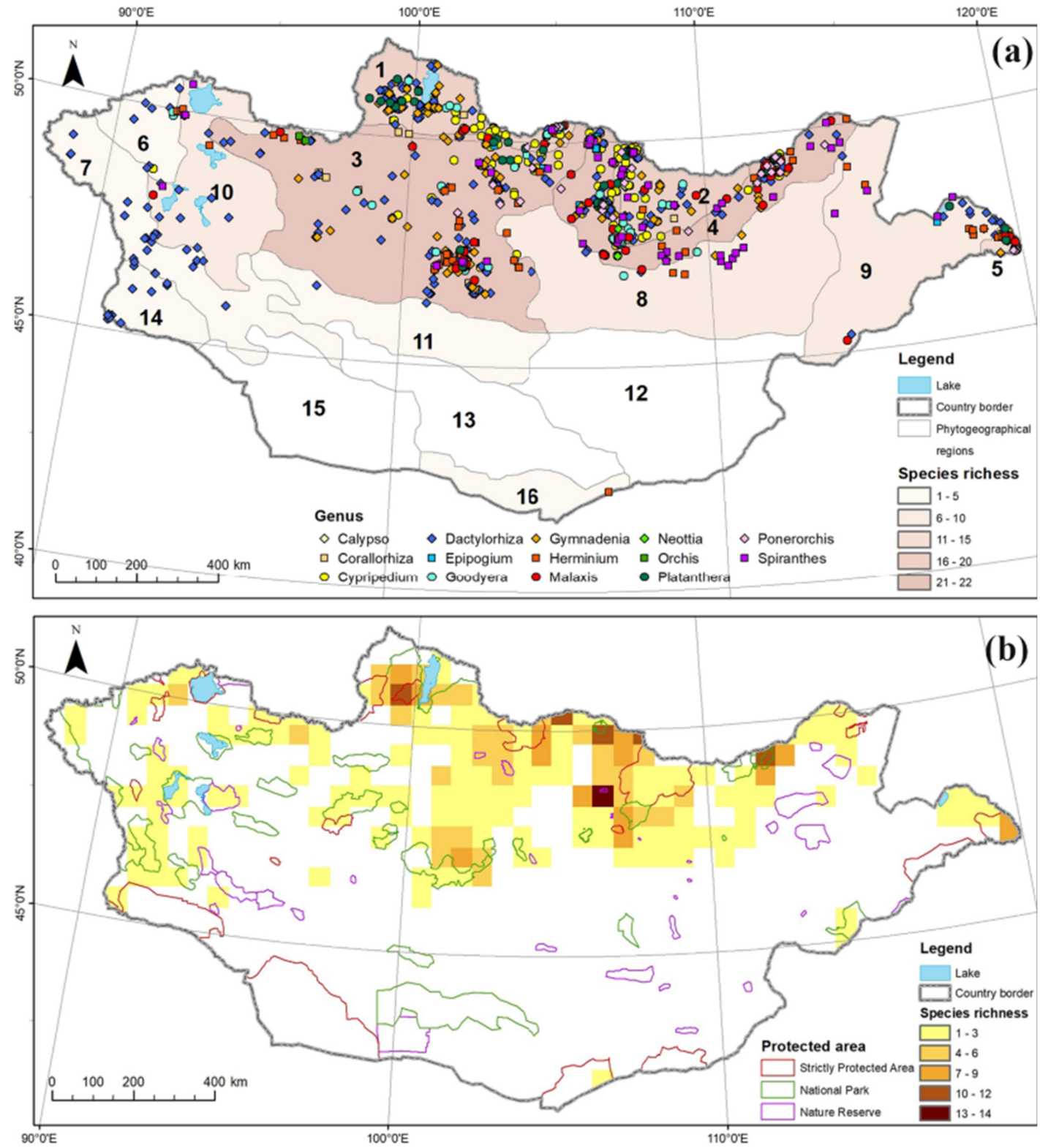

Figure 4. Species distribution pattern of Orchidaceae in Mongolia: (a) Species richness based on phytogeographical regions, with distribution points; 1-Khuvsgul, 2-Khentii, 3-Khangai, 4-Mongolian Dauria, 5-Foothills of Great Khingan, 6-Khovd, 7-Mongolian Altai, 8-Middle Khalkh, 9-East Mongolia, 10-Depression of Great Lakes, 11-Valley of Lakes, 12-East Gobi, 13-Gobi Altai, 14-Dzungarian Gobi, 15-Transaltai Gobi, 16-Alashan Gobi. (b) Species richness within protected areas based on grid cells.

\section{Discussion}

Overall, Orchidaceae checklist was thoroughly amended based on species distribution in the phytogeographical regions of Mongolia [23,24]. Recently, a comprehensive checklist including 27 orchid taxa was compiled by Urgamal et al. [25]. However, significant revisions were needed because some species had to be added or omitted (see Epipactis and Herminium), as well as the scientific names of some taxa were changed. Therefore, we critically revised all orchid taxa based on herbaria, literature, and field observations, and provided 26 taxa distribution maps with photographs of 18 taxa (Figures 1-3; Appendix A). The present distribution of certain genera was compared to that of previous research, and five genera showed major changes according to our review. Hence, the selected genera are explained in detail below. 


\subsection{Taxonomic Notes on Selected Genera}

Dactylorhiza Sw.

Dactylorhiza is the most difficult genus among orchids to identify because of morphological plasticity, ongoing evolution, and wide hybridization; therefore, the status of accepted species changes continually [37,42]. Currently, six taxa have been reported in Mongolia [23-25,43], but the number of species may vary depending on the author. One of the most taxonomically problematic groups is 'salina-aggregate', which is represented in the current overview by two species, viz. D. salina s.str. and D. umbrosa. It should be noted that the boundaries between them are very obscure, and that both taxonomical concepts are accepted here and determinations of herbarium specimens used in the study should be viewed as only preliminary. An alternative approach may be to accept one species in the group, D. salina s.l., or to further subdivide the group into smaller taxa. Another taxonomical problem is $D$. incarnata subsp. cruenta, which may be viewed by some taxonomists as a hyperchromic variant of $D$. incarnata with dots on the leaves, which is taxonomically identical to $D$. incarnata. Hence, further comprehensive studies on this genus are required.

Epipactis Zinn.

In Mongolia, two species of Epipactis, E. helleborine and E. palustris, were reported for the western part by Averyanov [30]; however, herbarium information was not provided. Since 1994, several checklists of Mongolian flora have noted that Epipactis has been recorded in western Mongolia based on the above-mentioned source. However, we only found one herbarium specimens of E. palustris (Figure 3f) from the herbarium TK labeled as "collected within Mongolia." When we revised the collection site, the locality fell outside Mongolia (in the territory of China), although not far from the Mongolian border. Additionally, Grubov [36] provided both species occurred in Tien Shan, East Siberia, and the Caucasus. Thus, both species were excluded from Urgamal et al. [25] according to the current study, but further findings of both species from western Mongolia are possible.

\section{Herminium L.}

In most of the literature, only one species, H. monorchis, has been reported in Mongolia [21,23,44]. Grubov [36] and Raskoti et al. [31] added one more species, H. alaschanicum Maxim., (Figure $3 \mathrm{~h}$ ) after its type collection. The herbarium is located in the Alashan Gobi region of Mongolia, near the border with China. However, Efimov [45] mistakenly stated that its location was in China. Further study is needed in the Alashan Gobi region to confirm whether this species is extant in the country.

Orchis L.

In the past, Orchis militaris L. (Figure 3g) was noted only in the Noyon Mountain area in the Mongolian Dauria region [23]. More recently, this species has been recorded in several regions of Mongolia [25], and we found four locations in the Khentii, Mongolian Dauria, and Khangai regions (Figure A21). In addition, several herbarium specimens of O. militaris were identified as Dactlorhiza spp. in the country. The correct herbarium specimens of $O$. militaris are preserved in the LE, MW, and HAL herbaria.

Spiranthes Rich.

Spiranthes amoena (M.Bieb.) Spreng. has been observed in several regions of Mongolia [23,24]. Later, S. ameona was proven to be a synonym of S. sinensis, which is mentioned in the Conspectus of Mongolian flora [25]. More recently, Pace et al. [32] investigated the Spiranthes sinensis complex based on molecular and morphological differences among Spiranthes taxa worldwide. According to Pace et al. [32], Mongolian S. sinensis and S. ameona are clearly identified as $S$. australis with hairy and densely pubescent flowering stems (Figure 1d).

\subsection{National Red List Assessement}

In the past, 16 species have been assessed according to the regional conservation status based on the most commonly used IUCN category, criterion B [9,28,29]. However, species distribution area sizes, such as EOO and AOO, were not estimated in the assessed species owing to limited distributional information. Therefore, we reassessed all orchid species 
based on more comprehensive collections, except Cypripedium $\times$ ventricosum, because of its hybrid status. In comparison to previous studies, some species belong to different categories (Table 2). For example, Dactylorhiza fuchsii was assessed as a critically endangered species with only one distribution point [28], but we found eight distribution points in the country, thus resulting in the species being as endangered (Figure A7).

Most Mongolian orchids co-occur in neighboring countries such as Russia and China [10,17], albeit with varying levels of threat status. For example, Cypripedium guttatum evaluated as a near threatened species in Mongolia, is considered an endangered species in China [10]. Similarly, Calypso bulbosa is critically endangered in Mongolia, whereas it is quite common in Russia [17]. Moreover, this species has not been observed in the wild in Mongolia over 10 years. Regardless of the co-occurrence with adjacent regions, we should give great consideration to the threatened species, which are valuable to Mongolian floral diversity.

\subsection{Species Richness Distribution}

We analyzed the 970 georeferenced distribution records of 26 orchid species based on $0.5^{\circ} \times 0.5^{\circ}$ grid cell size across 16 phytogeographical regions (Figure $4 \mathrm{a}, \mathrm{b}$ ). Mongolian orchid species richness is low in comparison to that in neighboring countries such as Russia (135 species [17]) and China (1582 species [10]), which might be explained by the relatively low intensity of field surveys, large size of unsettled land, and harsh continental climatic conditions. Our study revealed that the northern and north-eastern parts of the country have relatively diverse orchid flora compared to that in the western and southern regions of the country. This is certainly because of the optimum growth conditions for orchid species. In particular, orchids are constrained by edaphic environments and their relationships with mycorrhizal fungi and specialist pollinators $[16,46]$. The northern part of Mongolia is on the southern border of the Siberian boreal forest [47], and along the latitudinal gradient, precipitation decreases and temperature increases [48]. Therefore, northern and north-eastern Mongolia have a high number of orchid species compared to that in the arid steppes and deserts in the south and southeast.

Our results indicated that seven grid cells had a high diversity of orchids, primarily in the northern part of the country. In fact, most of the distribution areas were not well covered by protected areas. It should be noted that our findings were limited to orchid varieties; however, we did find many rare plants, particularly in the northern regions [26,49]. There are large-scale protected areas in the eastern steppe and southern Gobi of Mongolia, with the aim of protecting wild animals. However, the floral importance of this area is frequently overlooked. Therefore, concern for both wildlife and floral conservation simultaneously is critical, as they are integral parts of the same ecosystem. Through the establishment of protected areas, destruction of the habitat of dozens of taxa can be protected from activities such as mining, herb harvesting, and livestock grazing. Thus, we highlight the importance of conducting in-depth research on floral diversity and conservation gaps, especially in Mongolia's northern and central forest areas.

\section{Conclusions}

The present study provides valuable information on the orchid species richness of Mongolia, with a focus on current conservation status, grid distribution maps, and photo illustrations in the wild. We documented 26 orchid taxa in Mongolia, among which 12 species were threatened at the national level. Orchids are distributed mainly in the northern, eastern, and central parts of Mongolia (Figure 4a,b). Despite the species diversity of orchids being not particularly rich, the importance of protection cannot be neglected.

Author Contributions: Conceptualization, S.B.; methodology, S.B., Z.T. and S.V.; formal analysis, S.B., Z.T. and S.V.; resources, S.B., P.E., B.O., M.U., A.U., K.K. and T.N.; writing-original draft preparation, S.B.; writing-review and editing, K.O., S.V., P.E. and H.J.C.; supervision, B.O. and H.J.C.; project administration, H.J.C.; funding acquisition, H.J.C. All authors have read and agreed to the published version of the manuscript. 
Funding: This research was funded by the Korea National Arboretum, Korea, grant number KNA 1-2-38, 20-5; B.O. was funded by a "Seed Grant" from the National University of Mongolia, Mongolia, and P.E. was funded by RFBP, grant number 20-04-00561 and by the institutional research project grant number AAAA-A18-118030190056-4 of the Komarov Botanical Institute RAS.

Institutional Review Board Statement: Not applicable.

Informed Consent Statement: Not applicable.

Data Availability Statement: All the data were obtained from herbaria, field surveys, and literature and are available from the first author on reasonable request.

Acknowledgments: We thank B. Josef and Ch. Dulamsuren who provided the orchid photos included in this study. We also thank M. Legchenko and D. Slastunov for scanning the herbarium specimens in LE herbarium.

Conflicts of Interest: The authors declare no conflict of interest.

\section{Appendix A}

The grid distribution map of 26 orchid taxa in Mongolia. Data were mainly based on herbarium collections. Symbols are according to Table 1.

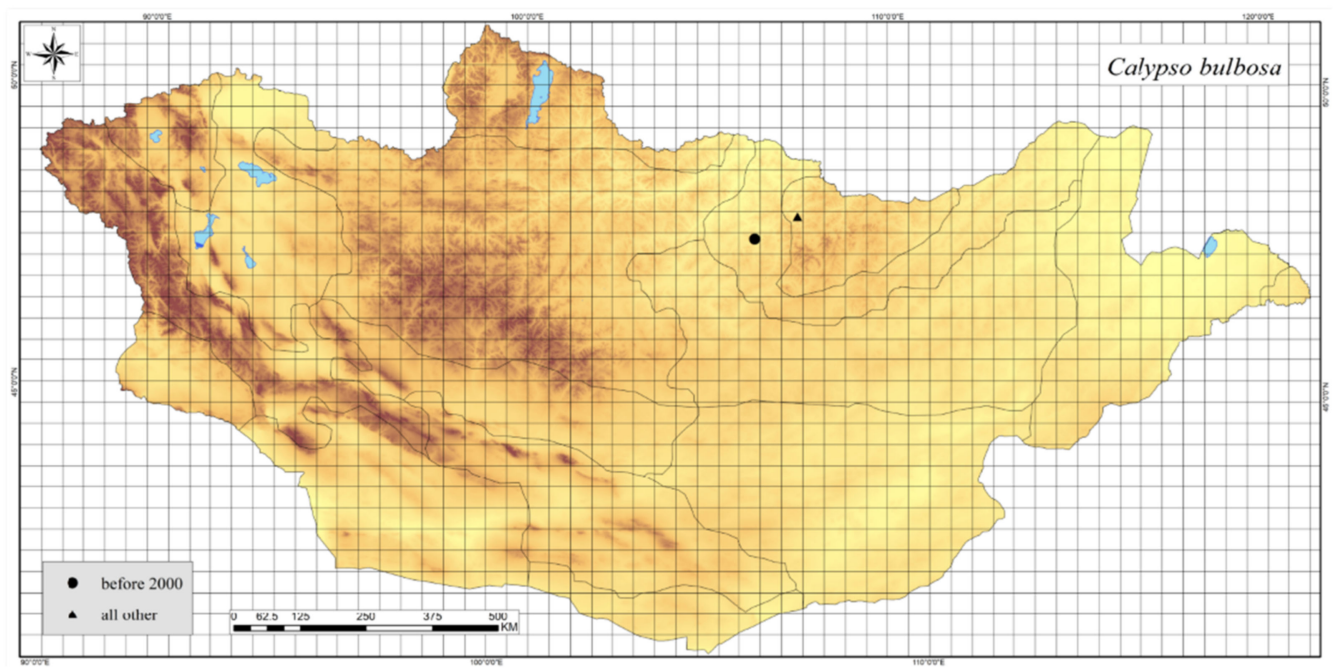

Figure A1. Distribution map of Calypso bulbosa in Mongolia.

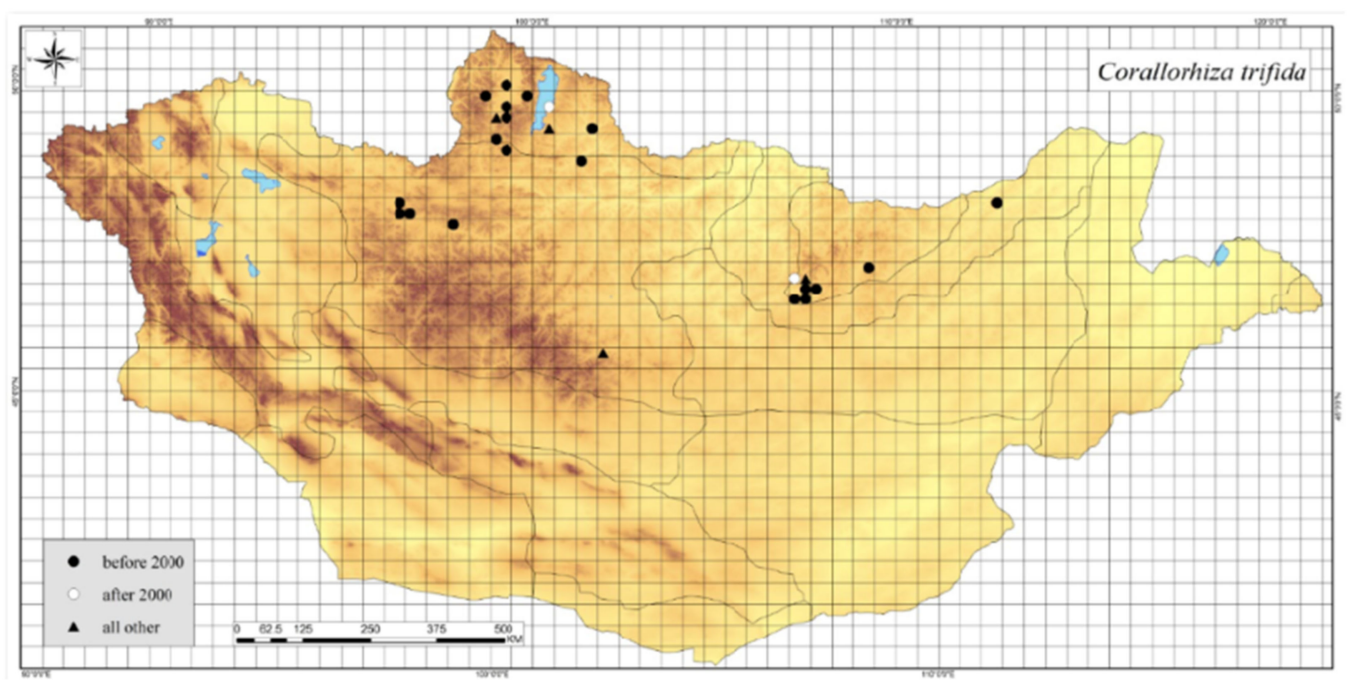

Figure A2. Distribution map of Corallorhiza trifida in Mongolia. 


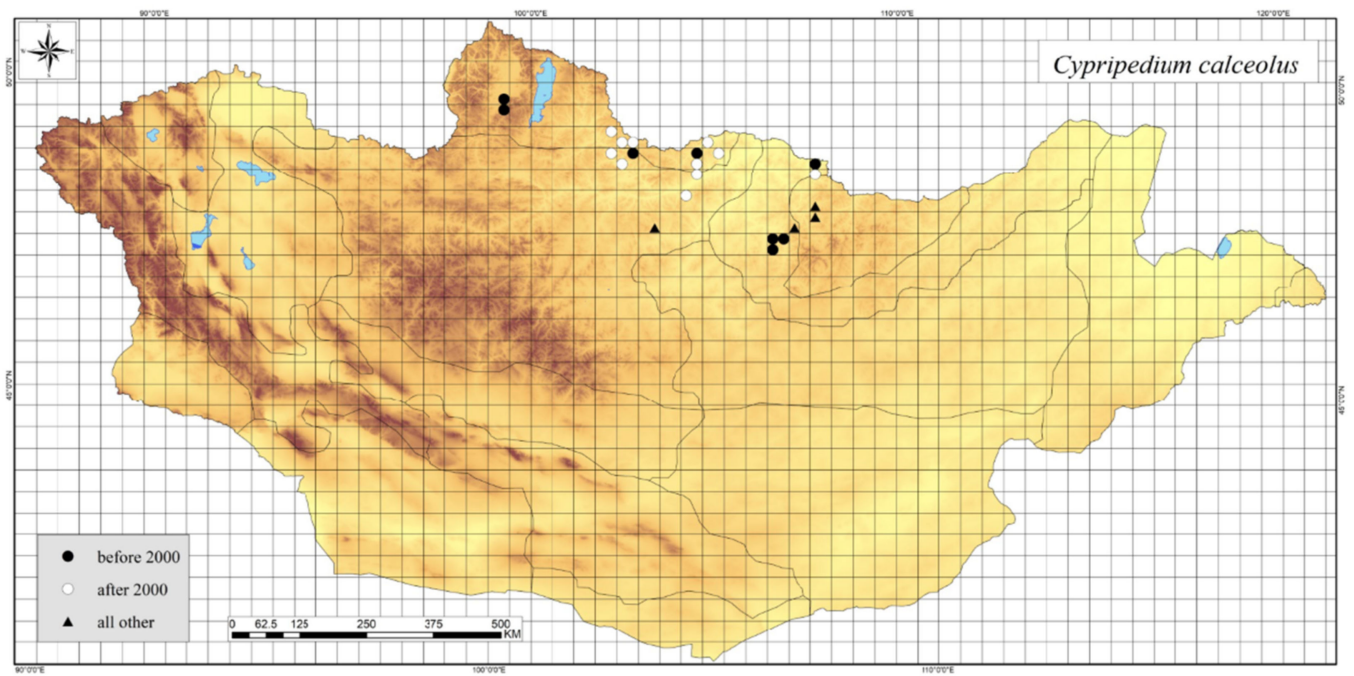

Figure A3. Distribution map of Cypripedium calceolus in Mongolia.

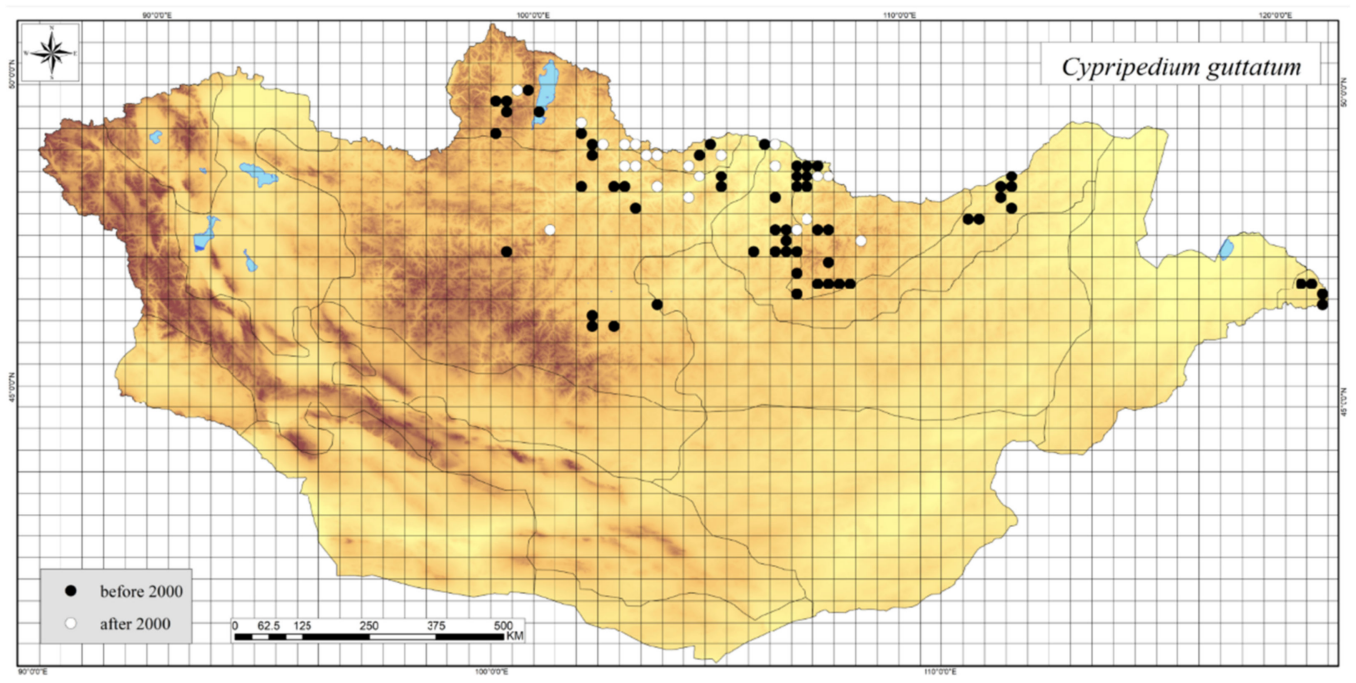

Figure A4. Distribution map of Cypripedium guttatum in Mongolia.

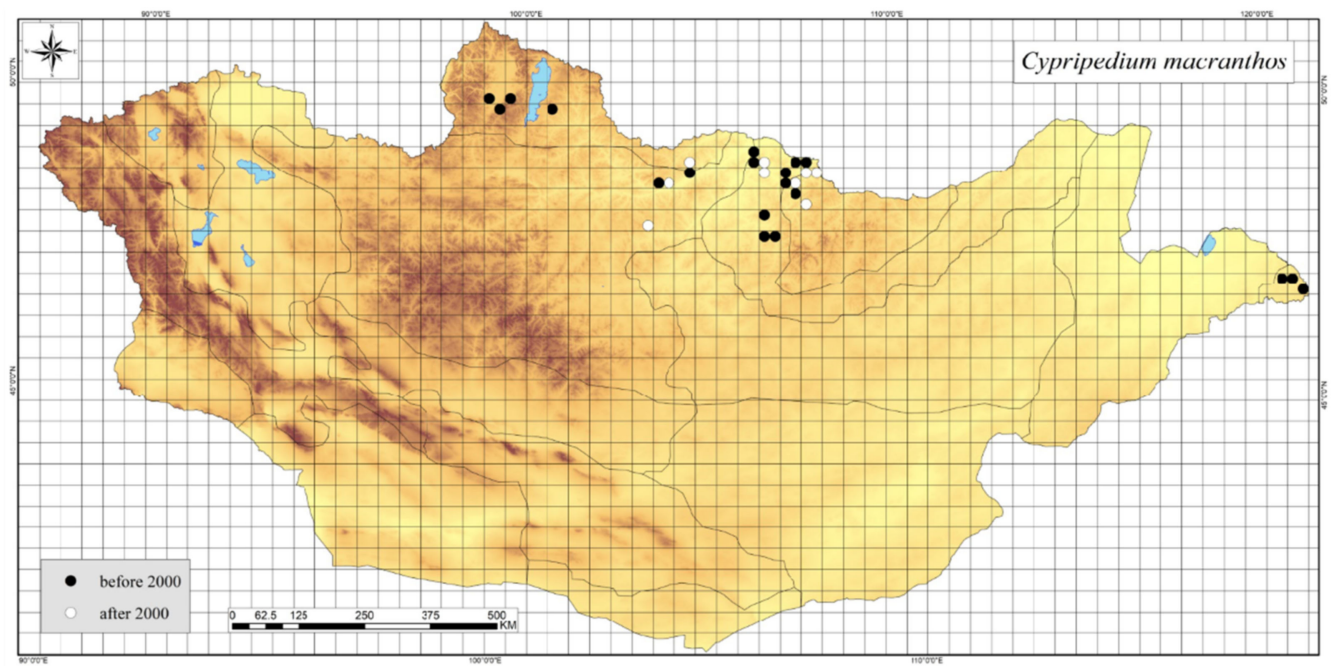

Figure A5. Distribution map of Cypripedium macronthos in Mongolia. 


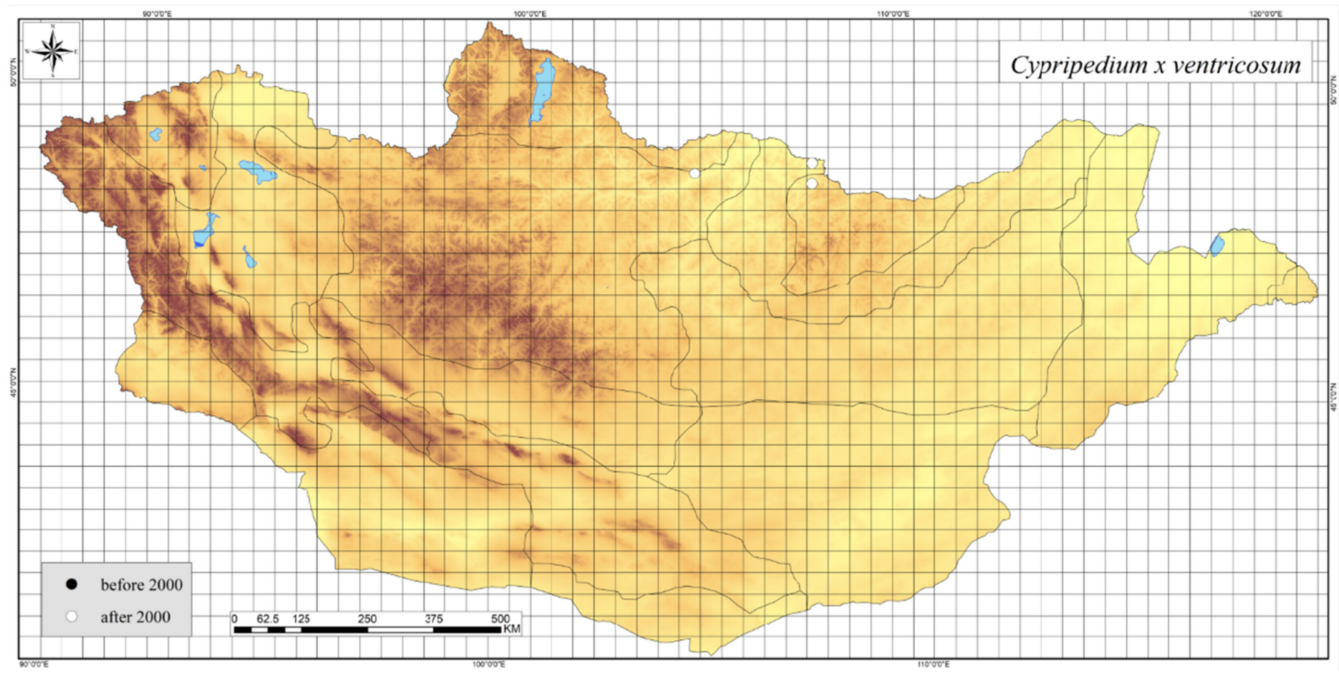

Figure A6. Distribution map of Cypripedium $\times$ ventricosum in Mongolia.

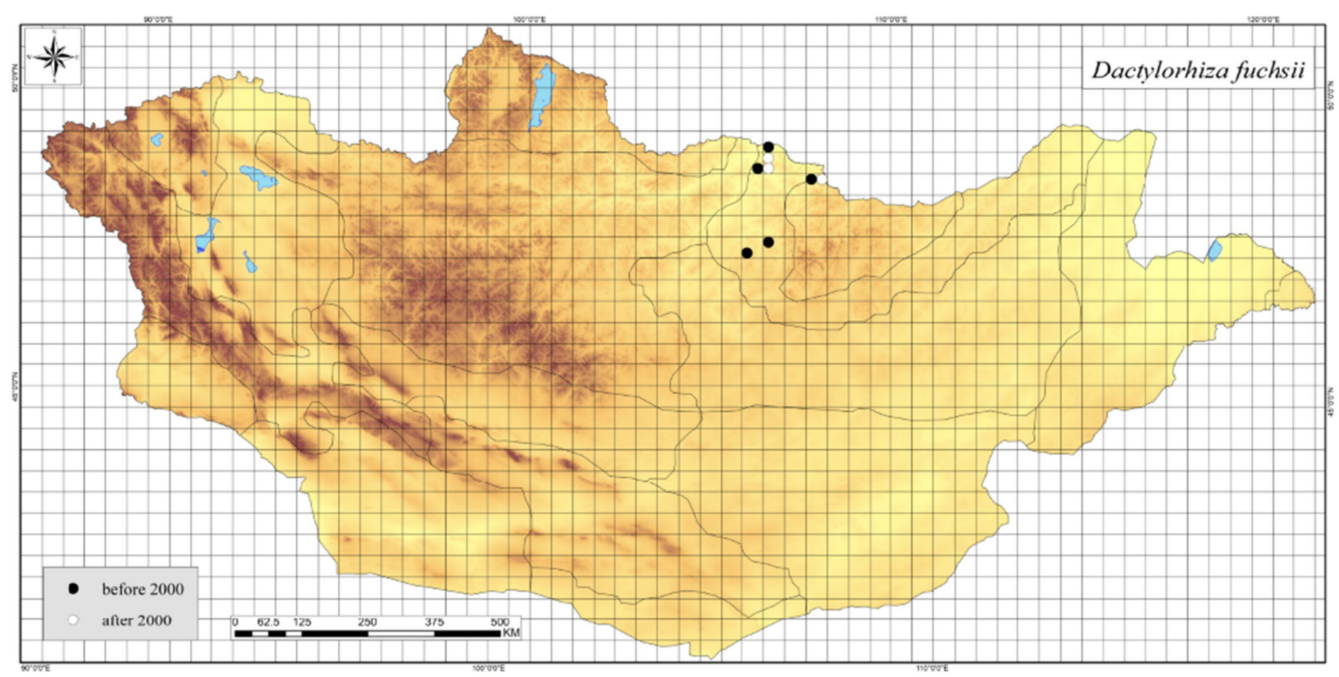

Figure A7. Distribution map of Dactylorhiza fuchsii in Mongolia.

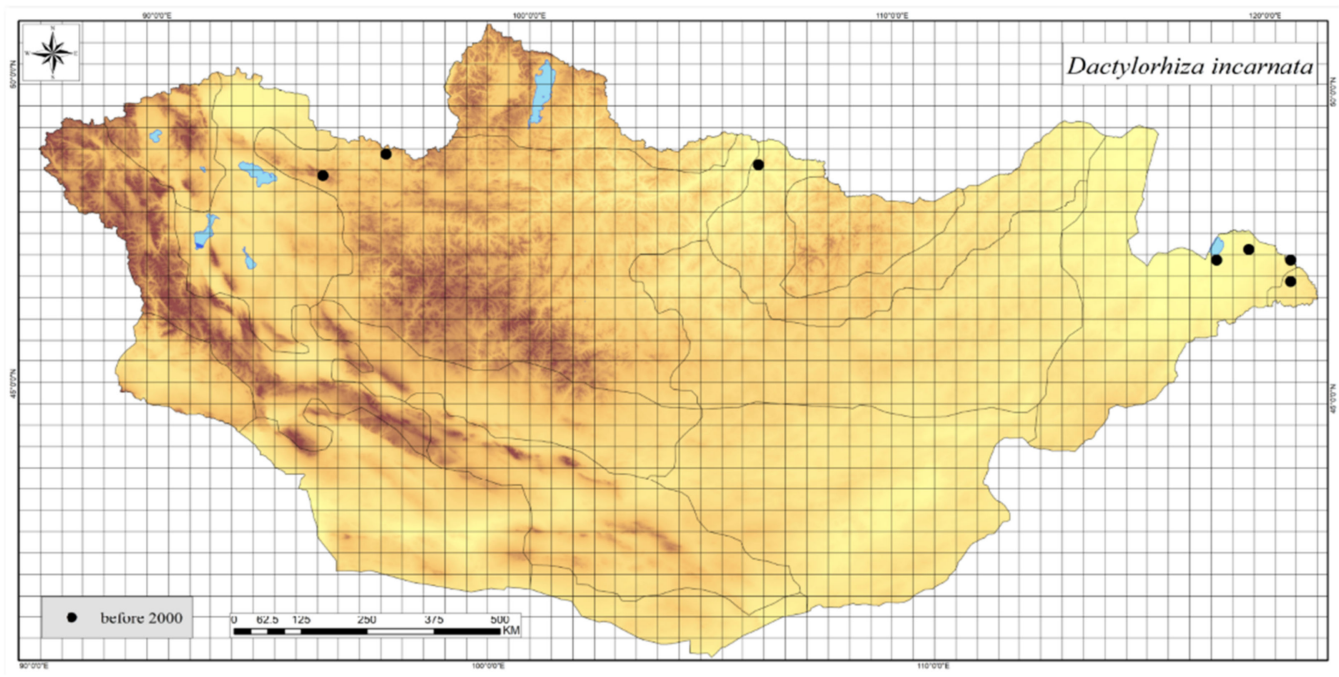

Figure A8. Distribution map of Dactylorhiza incarnata in Mongolia. 


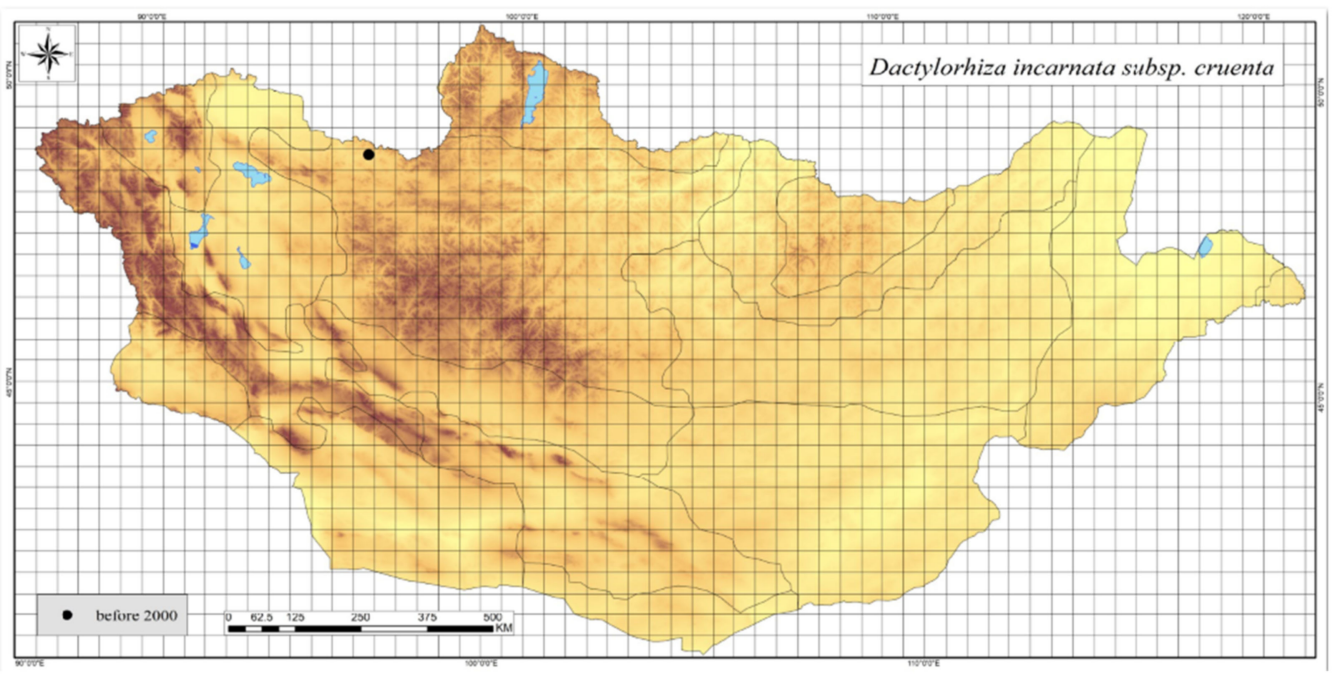

Figure A9. Distribution map of Dactylorhiza incarnata subsp. cruenta in Mongolia.

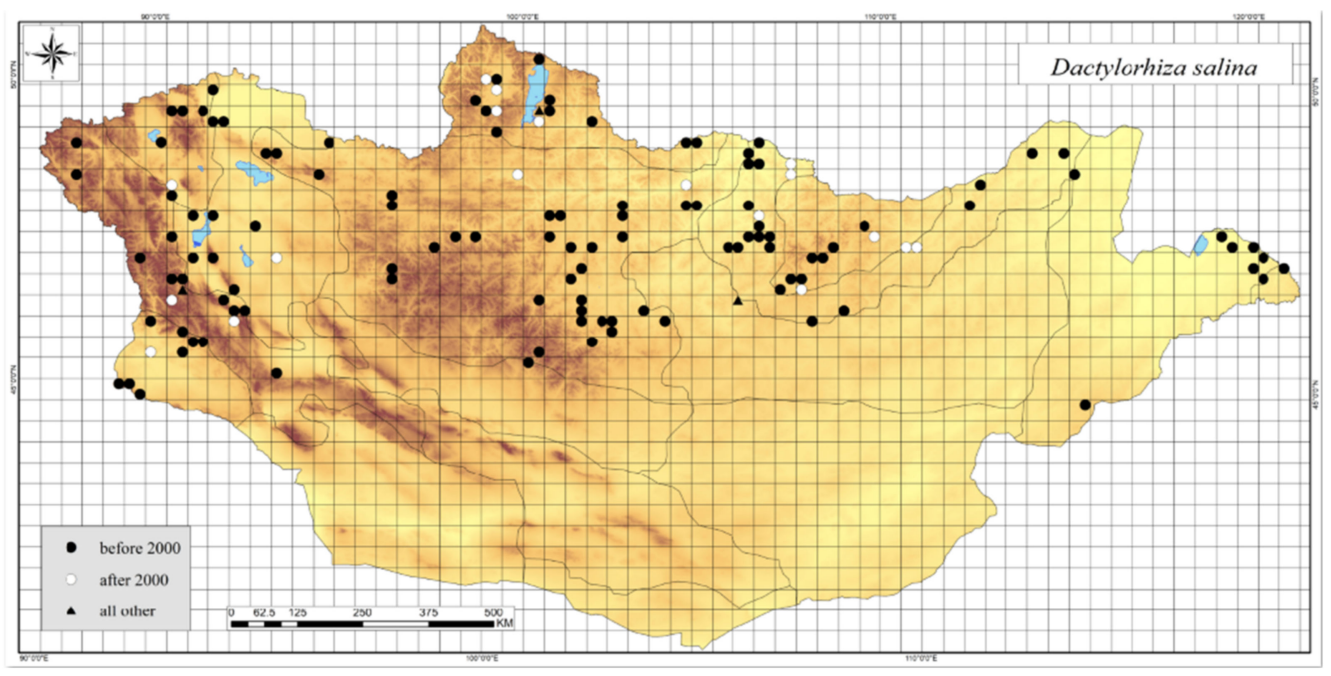

Figure A10. Distribution map of Dactylorhiza salina in Mongolia.

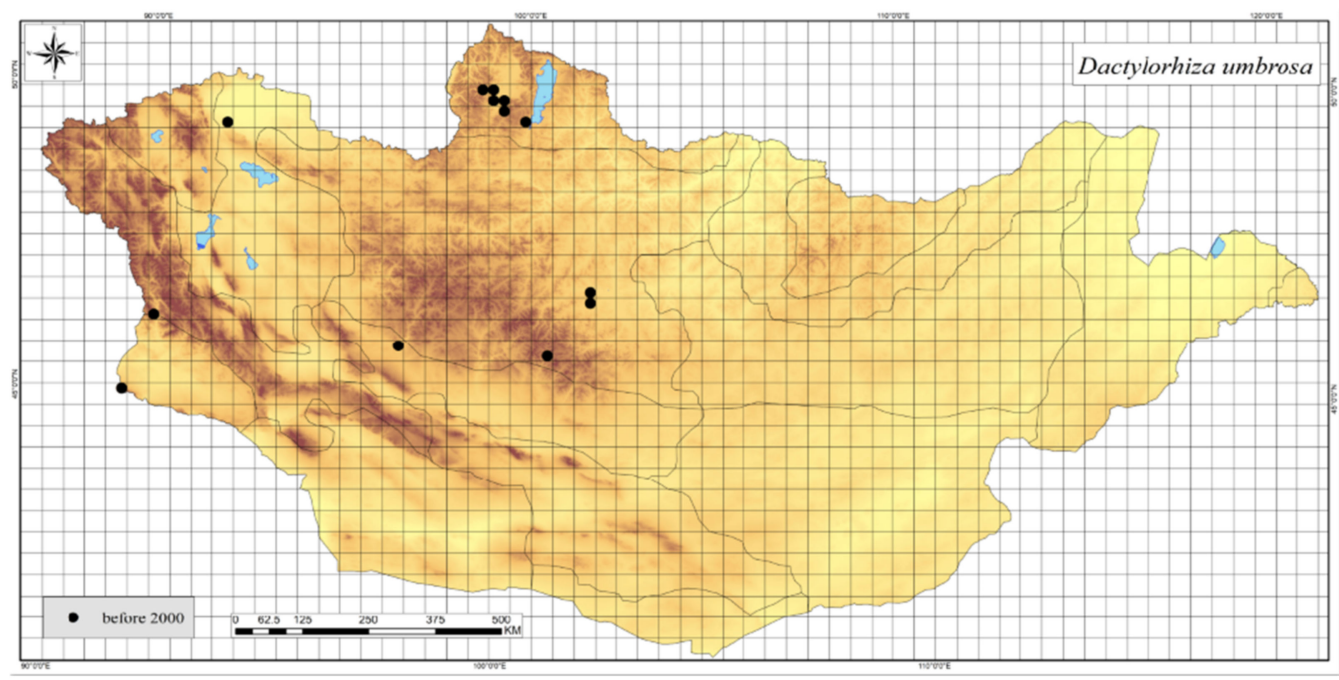

Figure A11. Distribution map of Dactylorhiza umbrosa in Mongolia. 


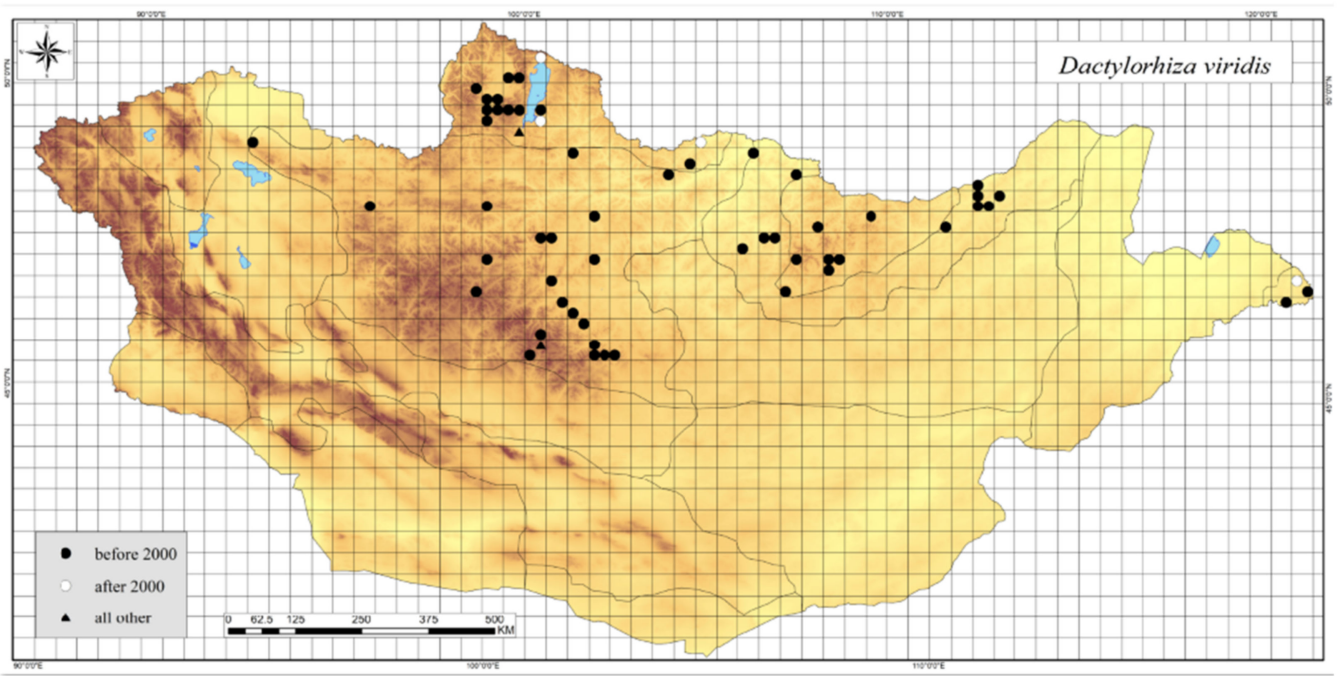

Figure A12. Distribution map of Dactylorhiza viridis in Mongolia.

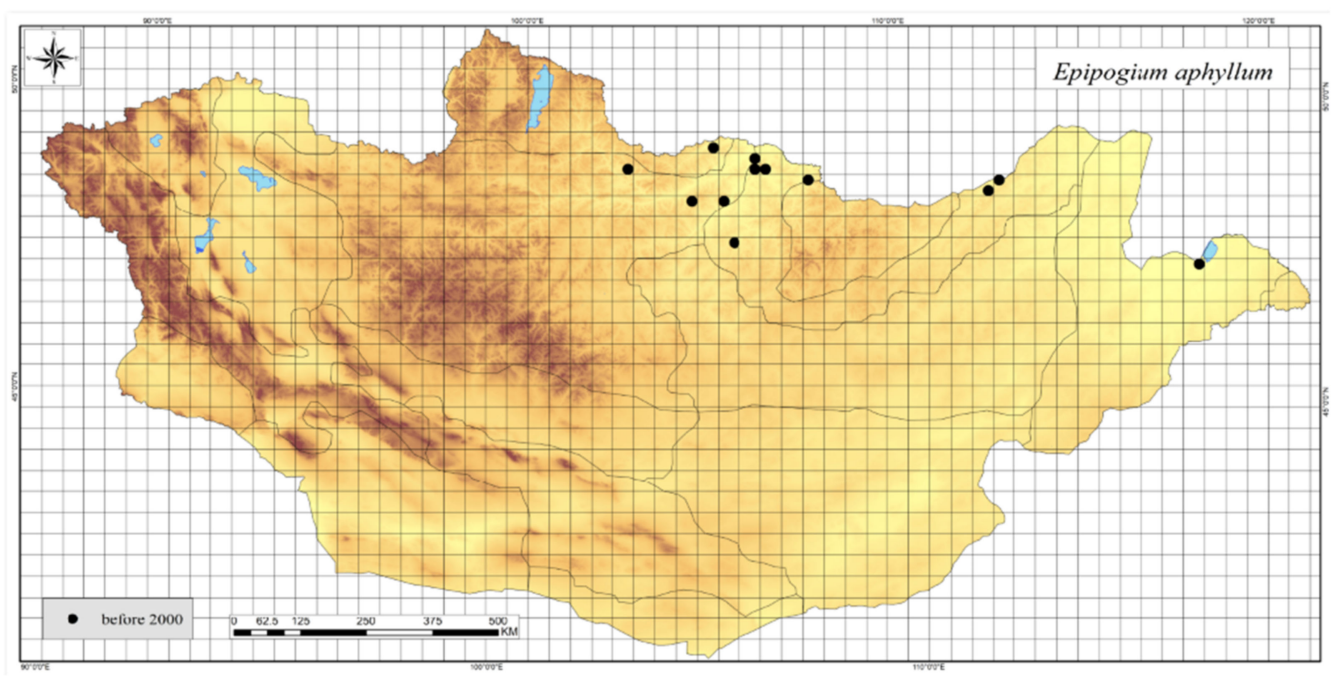

Figure A13. Distribution map of Epipogium aphyllum in Mongolia.

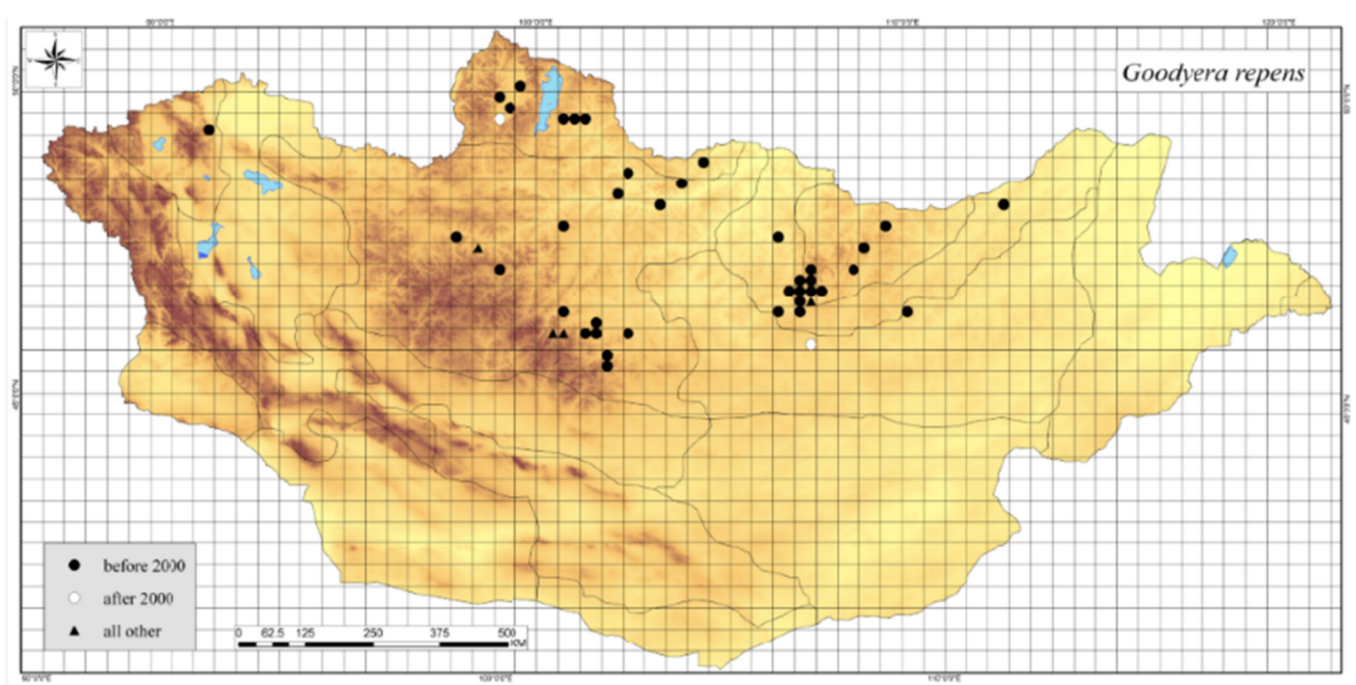

Figure A14. Distribution map of Goodyera repens in Mongolia. 


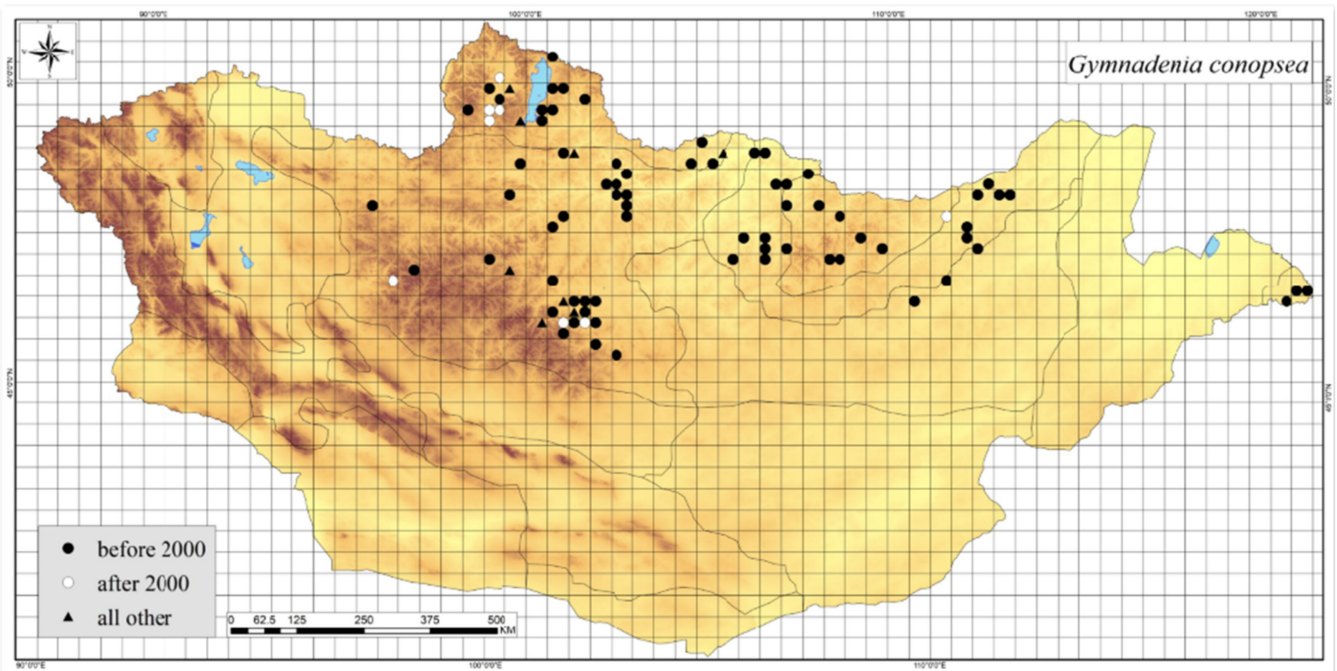

Figure A15. Distribution map of Gymnadenia conopsea in Mongolia.

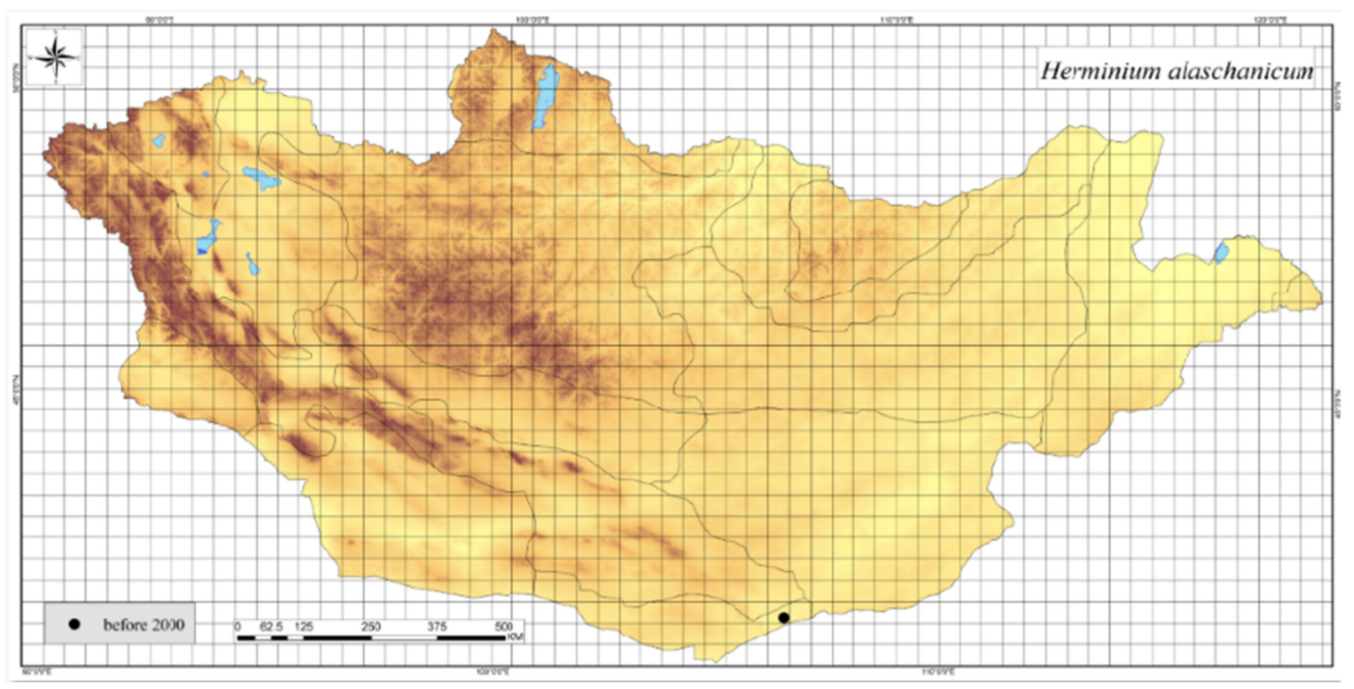

Figure A16. Distribution map of Herminium alashanicum in Mongolia.

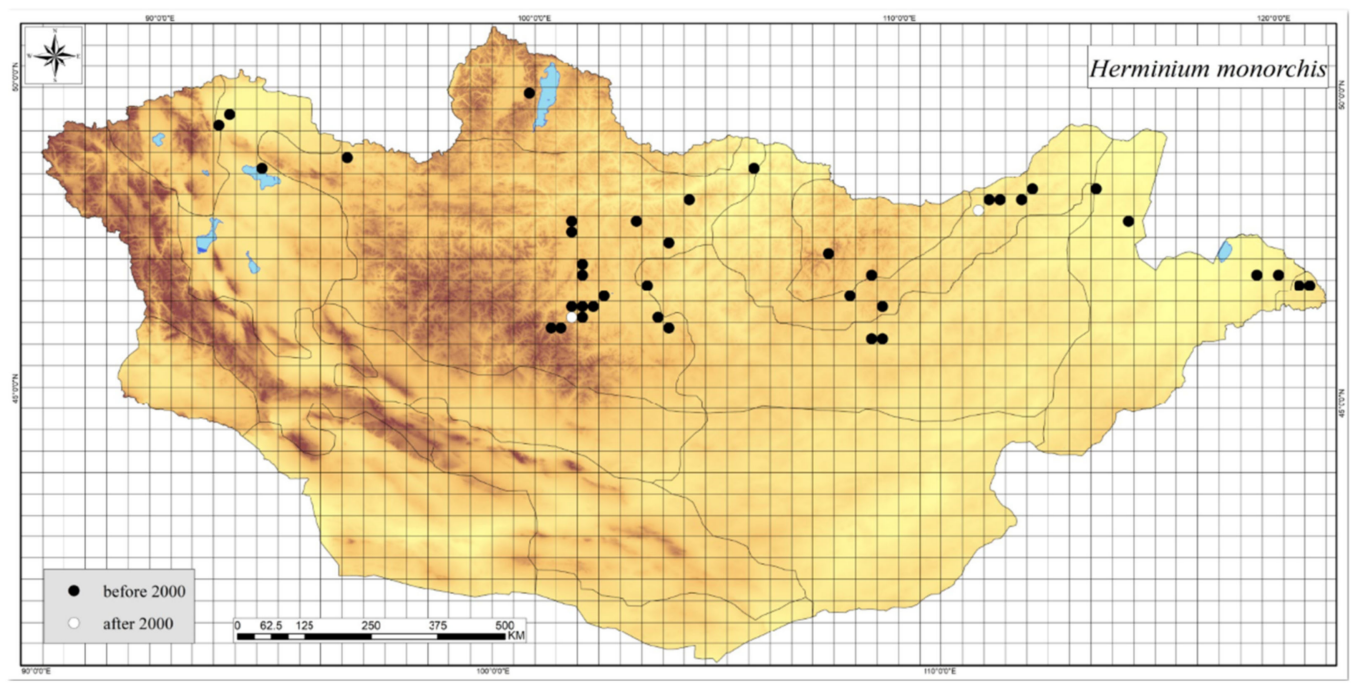

Figure A17. Distribution map of Herminium monorchis in Mongolia. 


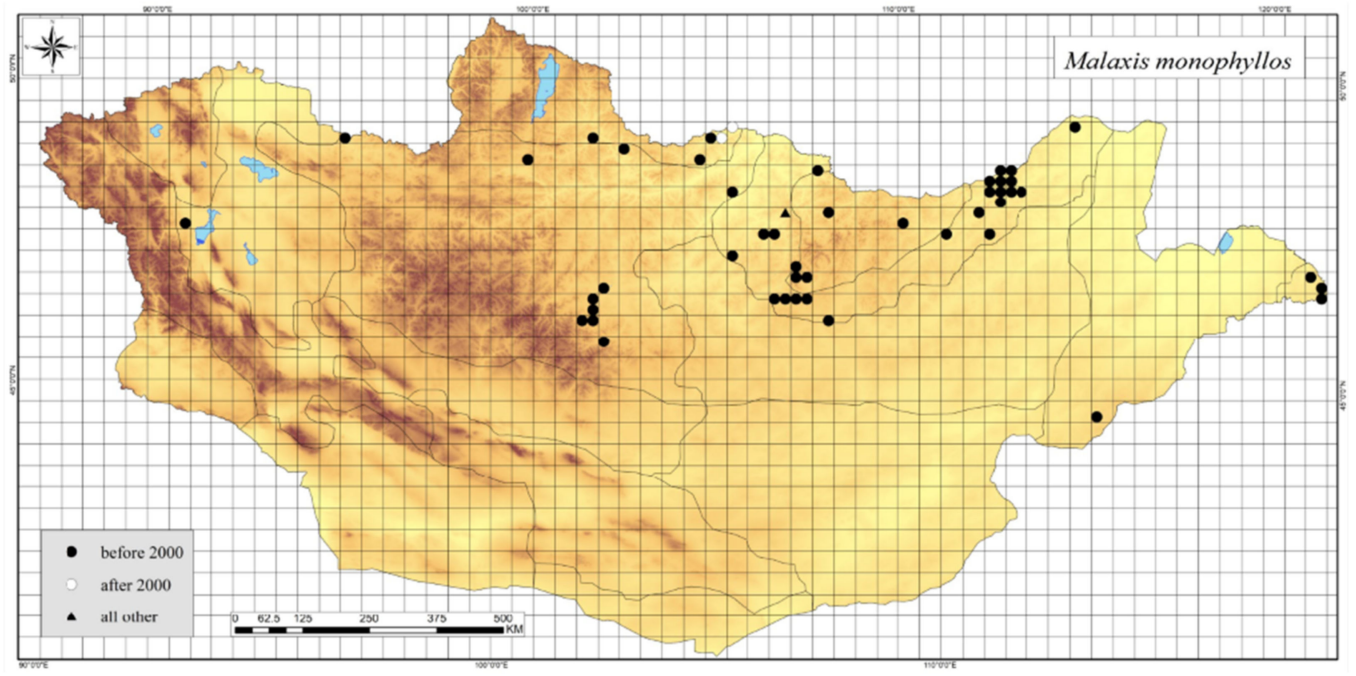

Figure A18. Distribution map of Malaxis monophyllos in Mongolia.

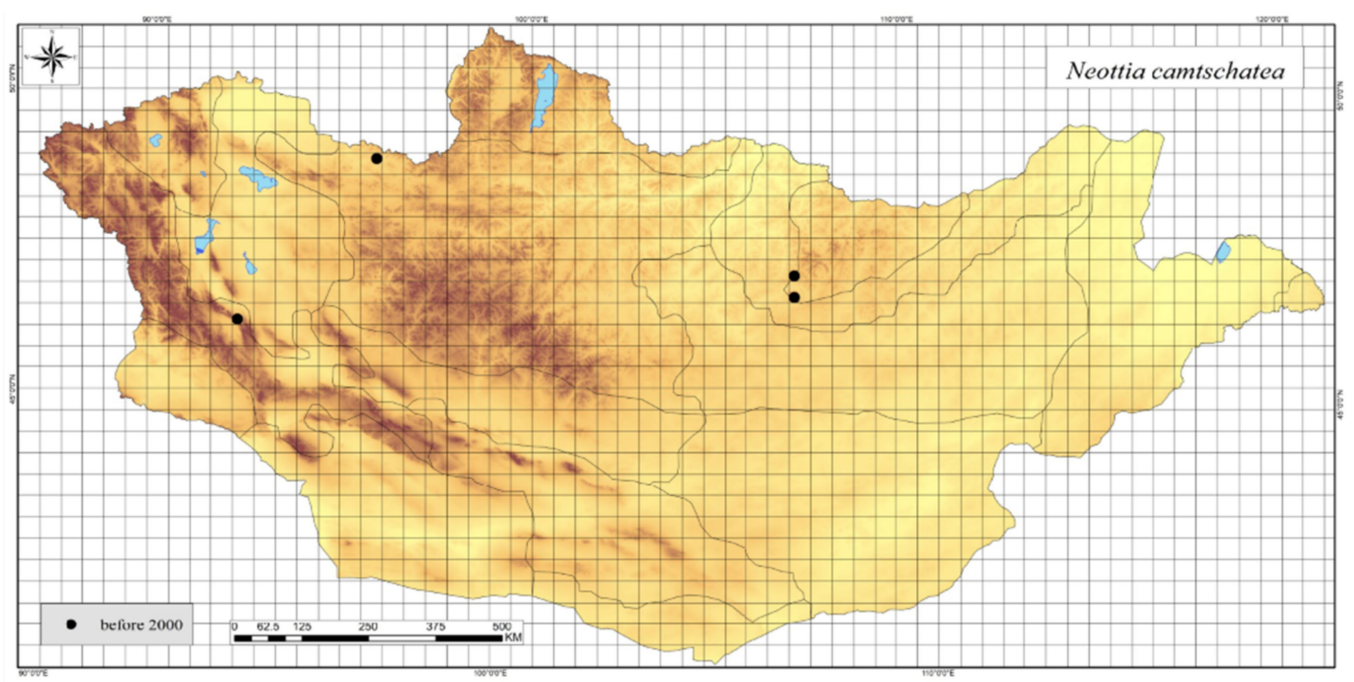

Figure A19. Distribution map of Neottia camtschatea in Mongolia.

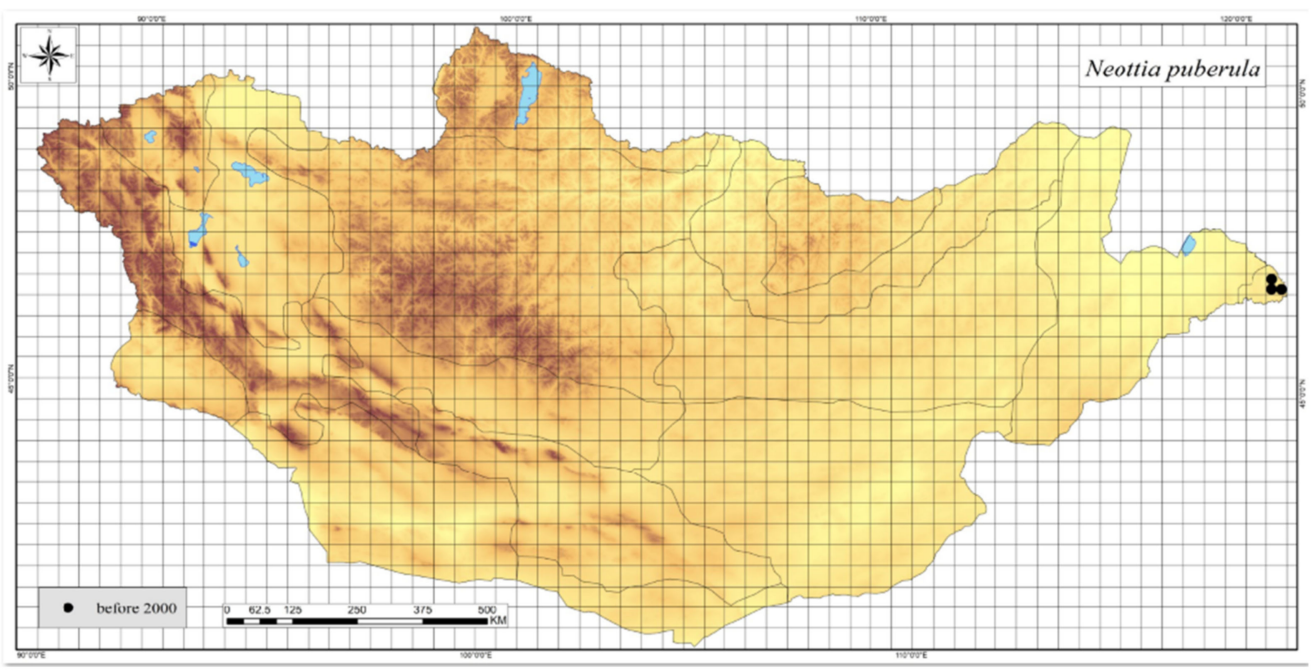

Figure A20. Distribution map of Neottia puberula in Mongolia. 


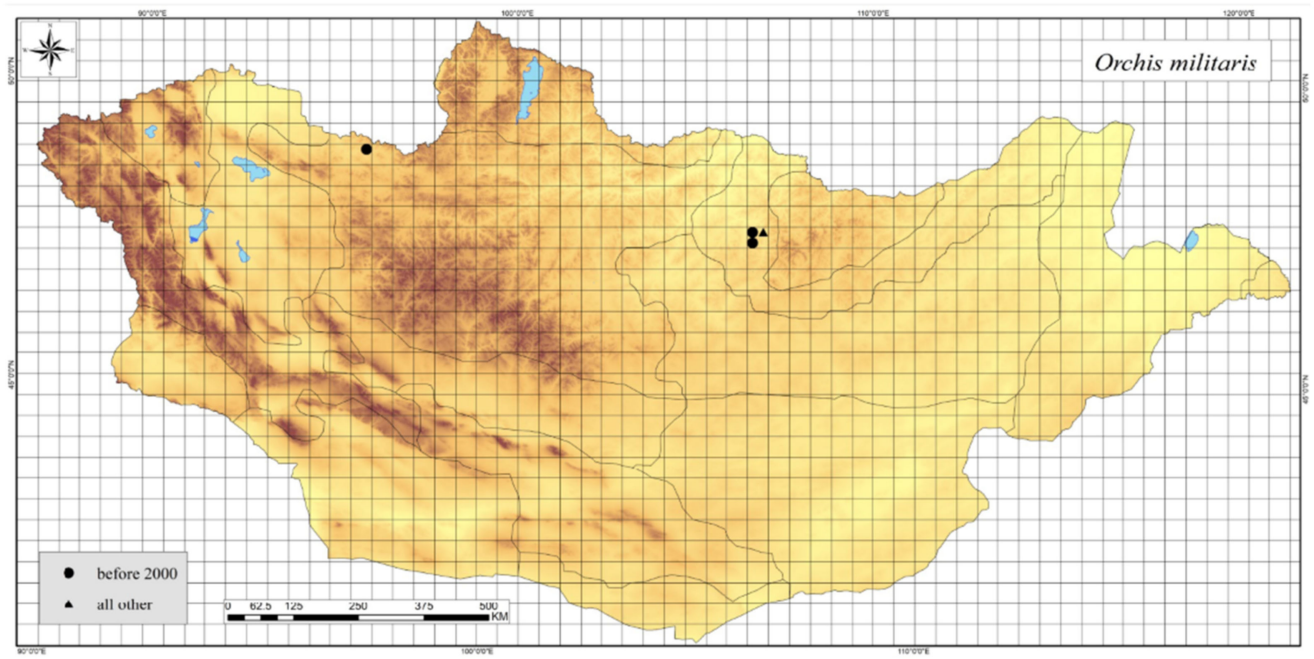

Figure A21. Distribution map of Orchis militaris in Mongolia.

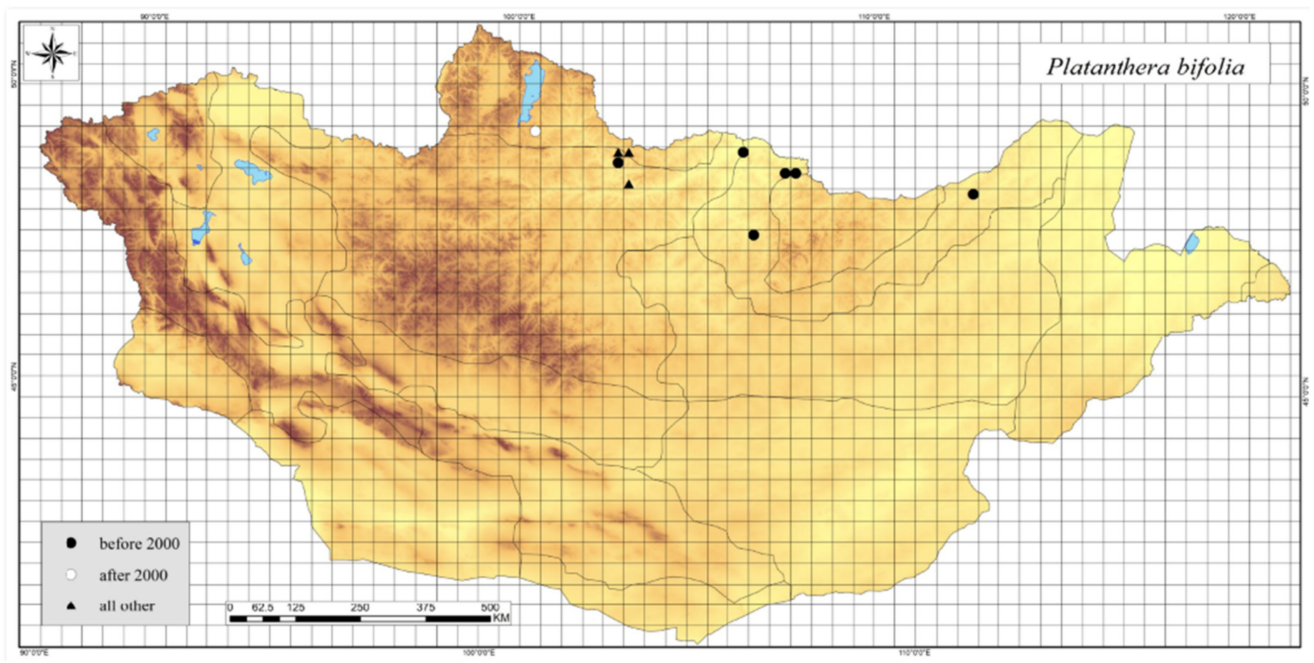

Figure A22. Distribution map of Platanthera bifolia in Mongolia.

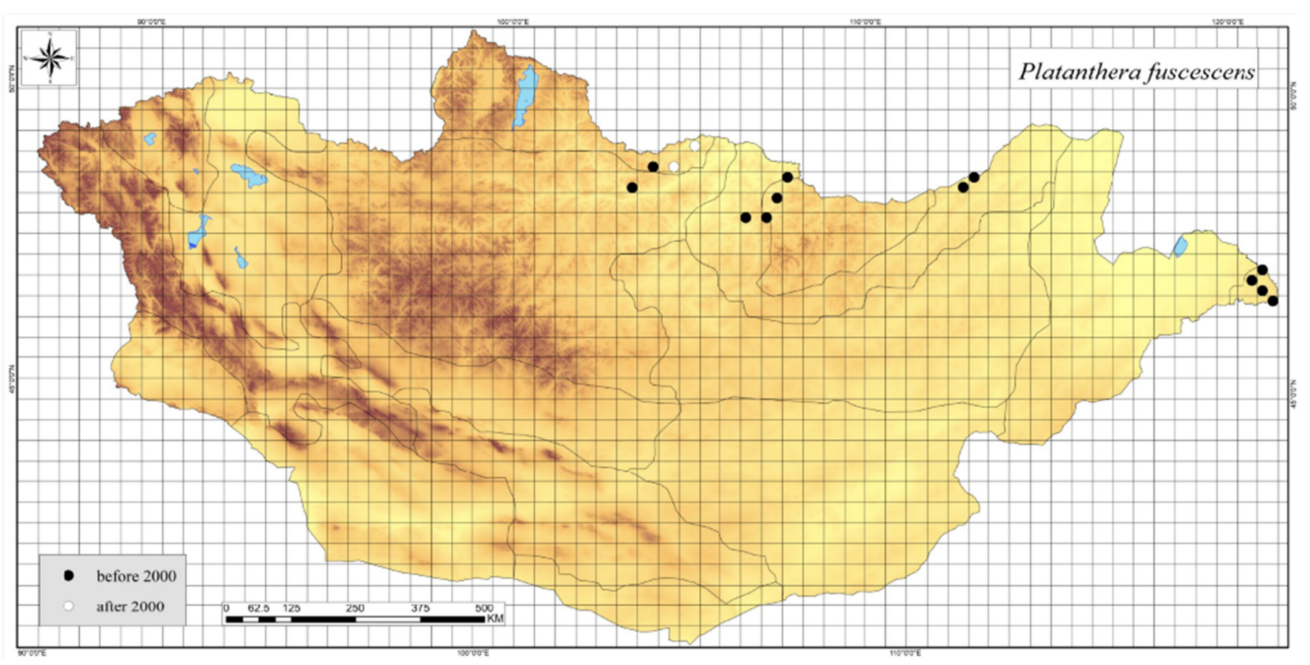

Figure A23. Distribution map of Platanthera fuscescens in Mongolia. 


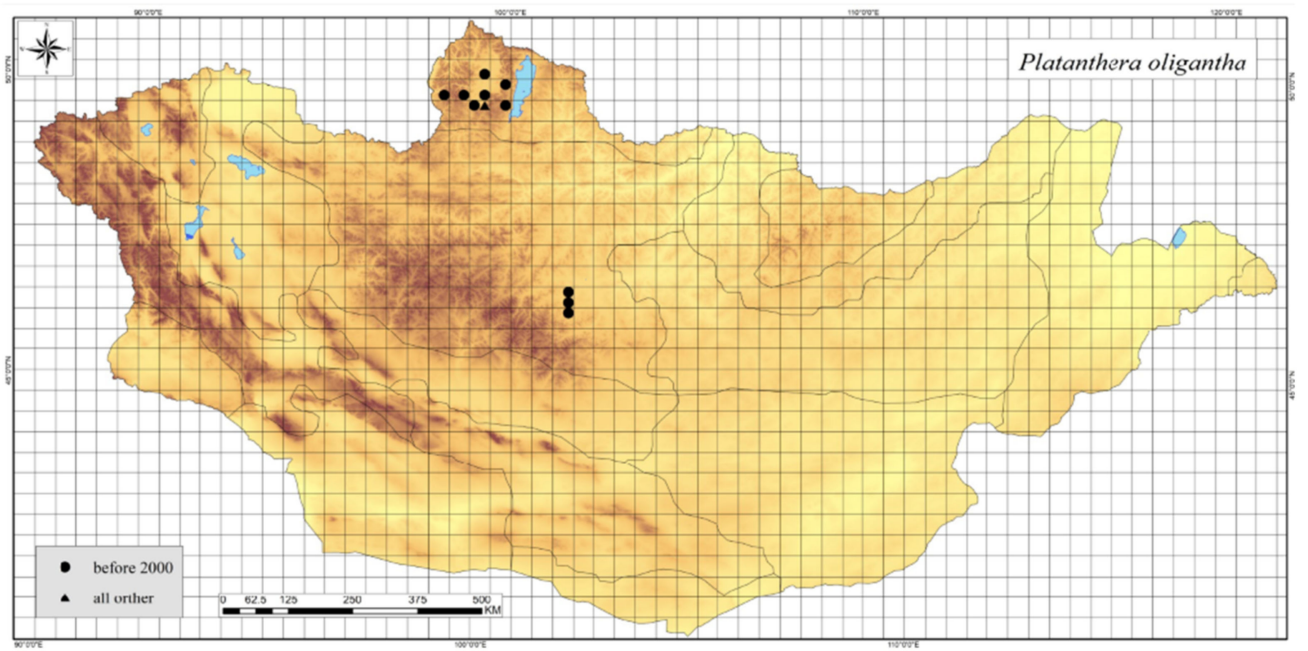

Figure A24. Distribution map of Platanthera oligantha in Mongolia.

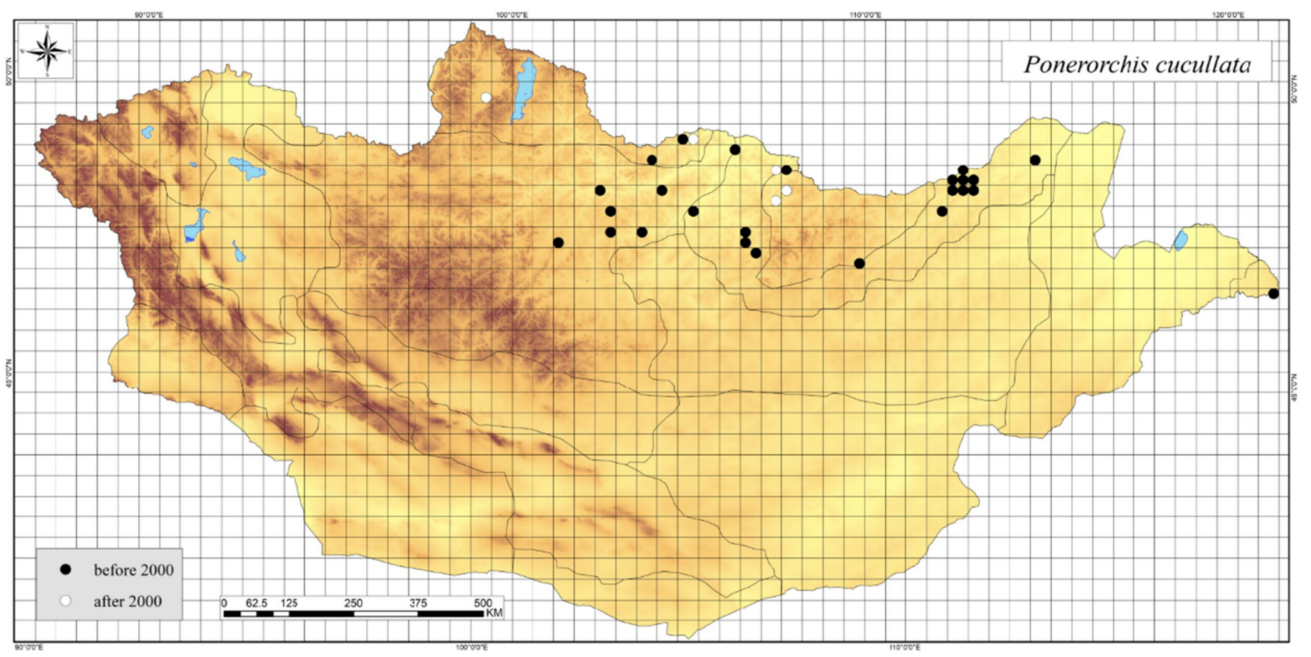

Figure A25. Distribution map of Ponerorchis cucullata in Mongolia.

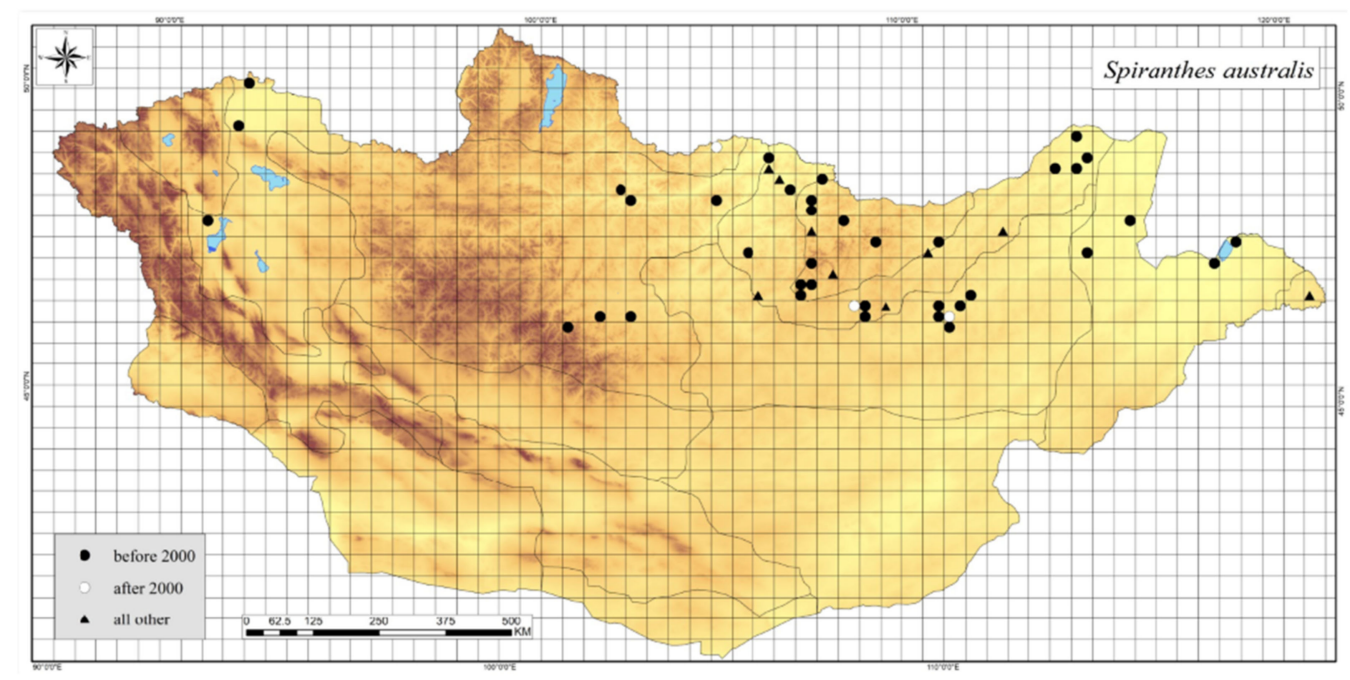

Figure A26. Distribution map of Spiranthes australis in Mongolia. 


\section{References}

1. Fay, M.F. Orchid conservation: How can we meet the challenges in the twenty-first century? Bot. Stud. 2018, 59, 1-16. [CrossRef] [PubMed]

2. Zizka, A.; Silvestro, D.; Vitt, P.; Knight, T.M. Automated conservation assessment of the orchid family with deep learning. Conserv. Biol. 2020, 35, 897-908. [CrossRef] [PubMed]

3. Swarts, N.D.; Dixon, K.W. Terrestrial orchid conservation in the age of extinction. Ann. Bot. 2009, 104, 543-556. [CrossRef] [PubMed]

4. Chase, M.W.; Cameron, K.M.; Freudenstein, J.V.; Pridgeon, A.M.; Salazar, G.; van den Berg, C.; Schuiteman, C. An updated classification of Orchidaceae. Bot. J. Linn. Soc. 2015, 177, 151-174. [CrossRef]

5. Hassler, M. World Orchids. Synonymic Checklist and Distribution of the Orchids of the World. Available online: https: / / www.worldplants.de/orchids/total-species-count (accessed on 11 May 2021).

6. IUCN 2019. The IUCN Red List of Threatened Species. Available online: http:/ / www.iucnredlist.org. (accessed on 1 March 2020).

7. Kreziou, A.; De Boer, H.; Gravendeel, B. Harvesting of salep orchids in north-western Greece continues to threaten natural populations. Oryx 2016, 50, 393-396. [CrossRef]

8. Kull, T.; Selgis, U.; Pecina, M.V.; Metsare, M.; Ilves, A.; Tali, K.; Sepp, K.; Kull, K.; Shefferson, R.P. Factors influencing IUCN threat levels to orchids across Europe on the basis of national red lists. Ecol. Evol. 2016, 6, 6245-6265. [CrossRef]

9. Oyuntsetseg, B.; Baasanmunkh, S.; Nyambayar, D.; Batkhuu, N.O.; Choi, H.J.; Chung, G.Y. The Conservation Status of 100 Rare Plants in Mongolia; Korea National Arboretum: Pocheon, Korea, 2018; p. 232.

10. Liu, H.; Liu, Z.; Jin, X.; Gao, J.; Chen, Y.; Liu, Q.; Zhang, D.Y. Assessing conservation efforts against threats to wild orchids in China. Biol. Conserv. 2020, 243, 108484. [CrossRef]

11. Rankou, H.; Bilz, M. The IUCN Red List of Threatened Species. Available online: http://dx.doi.org/10.2305/IUCN.UK.2014-1.RLTS. T162021A43316125.en (accessed on 15 April 2021).

12. Jakubska-Busse, A.; Tsiftsis, S.; Śliwiński, M.; Křenová, Z.; Djordjević, V.; Steiu, C.; Kolanowska, M.; Efimov, P.; Hennigs, S.; Lustyk, P.; et al. How to Protect Natural Habitats of Rare Terrestrial Orchids Effectively: A Comparative Case Study of Cypripedium calceolus in Different Geographical Regions of Europe. Plants 2021, 10, 404. [CrossRef]

13. Khapugin, A.A.; Chugunov, G.G.; Vargot, E.V. Cypripedium calceolus (Orchidaceae) in central Russia: A case study for its populations in two protected areas in the Republic of Mordovia (Russia). Lankesteriana 2017, 17, 417-431. [CrossRef]

14. Kolanowska, M.; Jakubska-Busse, A. Is the lady's-slipper orchid (Cypripedium calceolus) likely to shortly become extinct in Europe? Insights based on ecological niche modelling. PLoS ONE 2020, 15, e0228420. [CrossRef]

15. Zhang, Z.; Yan, Y.; Tian, Y.; Li, J.; He, J.-S.; Tang, Z. Distribution and conservation of orchid species richness in China. Biol. Conserv. 2015, 181, 64-72. [CrossRef]

16. Gaskett, A.C.; Gallagher, R.V. Orchid diversity: Spatial and climatic patterns from herbarium records. Ecol. Evol. 2018, 8, 11235-11245. [CrossRef]

17. Efimov, P.G. Orchids of Russia: Annotated checklist and geographic distribution. Nat. Conserv. Res. 2020, 5, 1-18. [CrossRef]

18. Juiling, S.; Sabah, U.M.; Leon, S.K.; Jumian, J.; Tsen, S.; Lee, Y.L.; Khoo, E.; Sugau, J.B.; Nilus, R.; Pereira, J.T.; et al. Conservation assessment and spatial distribution of endemic orchids in Sabah, Borneo. Nat. Conserv. Res. 2020, 5, 136-144. [CrossRef]

19. Stipkova, Z.; Kindlmann, P. Orchid Extinction over the Last 150 Years in the Czech Republic. Diversity 2021, 13, 78. [CrossRef]

20. Tsiftsis, S.; Tsiripidis, I. Temporal and spatial patterns of orchid species distribution on Greece: Implications for conservation. Biodivers. Conserv. 2020, 29, 3461-3489. [CrossRef]

21. Djordjević, V.; Tsiftsis, S.; Lakušić, D.; Jovanović, S.; Stevanović, V. Orchid species richness and composition in relation to vegetation types. Wulfenia 2020, 27, 183-210.

22. Khapugin, A.A. A global systematic review on orchid data in protected areas. Nat. Conserv. Res. 2020, 5 (Suppl. 1), 19-33. [CrossRef]

23. Grubov, V.I. Key to Vascular Plants of Mongolia; Nauka: Leningrad, Russia, 1982; p. 503. (In Russian)

24. Gubanov, A.I. Conspectus of Flora in Outer Mongolia; Valang: Moscow, Russia, 1996; p. 136. (In Russian)

25. Urgamal, M.; Oyuntsetseg, B.; Nyambayar, D.; Dulamsuren, C. Conspectus of the Vascular Plants of Mongolia; Admon Printing: Ulaanbaatar, Mongolia, 2014; pp. 42-44.

26. Baasanmunkh, S.; Oyuntsetseg, B.; Oyundelger, K.; Khaliunaa, K.; Urgamal, M.; Batkhuu, N.-O.; Shiga, T.; Chung, G.Y.; Choi, H.J. Contribution to the knowledge on the flora of northern Mongolia. J. Asia. Pac. Biodivers. 2019, 12, 643-660. [CrossRef]

27. Urgamal, M.; Oyuntsetseg, B. Atlas of the Endemic Vascular Plants of Mongolia; Bembi San: Ulaanbaatar, Mongolia, 2017.

28. Nyambayar, D.; Oyuntsetseg, B.; Tungalag, R. Mongolian Red List and Conservation Action Plans of Plants; Admon Printing: Ulaanbaatar, Mongolia, 2011; p. 183.

29. Urgamal, M.; Oyuntsetseg, B.; Tungalag, R.; Gundegmaa, V.; Oyundari, C.; Tserendulam, C.; Munkh-Erdene, T.; Solongo, S. Mongolian Plants Red List 2; Bembi San: Ulaanbaatar, Mongolia, 2019; p. 230. (In Mongolian)

30. Averyanov, L.V. Review of the species of the family Orchidaceae in the Caucasus flora. Bot. Zhur. 1994, 79, $108-127$.

31. Raskoti, B.B.; Schuiteman, A.; Jin, W.T.; Jin, X.H. A taxonomic revision of Herminium L. (Orchidoideae, Orchidaceae). PhytoKeys 2017, 79, 1-74. [CrossRef] [PubMed]

32. Pace, M.J.; Cameron, K.M.; Frericks, J.; Giraldo, G.; Lehnebach, C.A. Illuminating the systematics of the Spiranthes sinensis species complex (Orchidaceae): Ecological speciation with little morphological differentiation. Bot. J. Linn. Soc. 2018, 189, 36-62. [CrossRef]

33. Efimov, P.G. A revision of Platanthera (Orchidaceae; Orchidoideae; Orchideae) in Asia. Phytotaxa 2016, 254, 1-233. [CrossRef] 
34. Thiers, B. Index Herbariorum: A Global Directory of Public Herbaria and Associated Staff. New York Botanical Garden's Virtual Herbarium. Available online: http:/ / sweetgum.nybg.org/ih/ (accessed on 1 December 2020).

35. Rilke, S.; Najmi, U.; Schnittler, M. Contributions to 'E-Taxonomy'—A virtual approach to the flora of Mongolia (FloraGREIF). Feddes. Repert. 2013, 123, 219-232. [CrossRef]

36. Grubov, V.I. Plants of Central Asia: Plant Collection from China and Mongolia; CRC Press: Boca Raton, FL, USA, 2003; Volume 7, p. 186. [CrossRef]

37. Efimov, P.G.; Phillipov, E.G.; Krivenko, D.A. Allopolyploid speciation in Siberian Dactylorhiza (Orchidaceae, Orchidoideae). Phytotaxa 2016, 258, 101-120. [CrossRef]

38. IUCN. Guidelines for Using the IUCN Red List Categories and Criteria; Version 14; Prepared by the Standards and Petitions Subcommittee. 2019. Available online: https://www.iucnredlist.org/resources/redlistguidelines (accessed on 15 August 2020).

39. Dauby, G.; Stévart, T.; Droissart, V.; Cosiaux, A.; Deblauwe, V.; Simo-Droissart, M.; Sosef, M.S.M.; Lowry, P.P.; Schatz, G.E.; Gereau, R.E.; et al. ConR: An R package to assist large-scale multispecies preliminary conservation assessments using distribution data. Ecol. Evol. 2017, 7, 11292-11303. [CrossRef]

40. R Core Team. R: A Language and Environment for Statistical Computing; R Foundation for Statistical Computing: Vienna, Austria, 2016; Available online: https:/ / www.R-project.org/ (accessed on 24 December 2020).

41. Esri. ArcGIS Desktop: Release 10.2; Environmental Systems Research Institute: Redlands, CA, USA, 2012.

42. Pillon, Y.; Fay, M.F.; Shipunov, A.B.; Chase, M.W. Species diversity versus phylogenetic diversity: A practical study in the taxonomically difficult genus Dactylorhiza (Orchidaceae). Biol. Conserv. 2006, 129, 4-13. [CrossRef]

43. Baasanmunkh, S.; Oyuntsetseg, B.; Oyundari, C.; Oyundelger, K.; Urgamal, M.; Darikhand, D.; Soninkhishig, N.; Nyambayar, D.; Khaliunaa, K.; Tsegmed, Z.; et al. The vascular plant diversity of Dzungarian Gobi in western Mongolia, with an annotated checklist. Phytotaxa 2021, 501, 1-55. [CrossRef]

44. Shukherdorj, B.; Shiga, T.; Batlai, O.; Wesche, K.; Ritz, C.M.; Khurelbaatar, K.; Kim, J.Y.; Jo, H.J.; Nyam-Osor, B.; Chung, G.Y.; et al. Contribution to the knowledge on the flora of Numrug Stirctly Protected Area and some parts of East Mongolia. J. Asia. Pac. Biodivers. 2019, 12, 284-301. [CrossRef]

45. Efimov, P.G. Additions to the orchidaceous part of the "Catalogues of the type specimens of the vascular plants" from Central and East Asia, Siberia and the Russian Far East kept in the Hebrarium of the Komarov Botanical Institute (LE). Novosti. Sist. Plant. Vasc. 2018, 49, 42-50. [CrossRef]

46. McCormick, M.K.; Jacquemyn, H. What constrains the distribution of orchid populations? New Phytol. 2014, 202, 392-400. [CrossRef]

47. Gunin, P.D.; Vostokova, E.A.; Dorofeyuk, N.I.; Tarasov, P.E.; Black, C.C. Vegetation Dynamics of Mongolia; Kluwer Academic Publishers: The Dordrecht, The Netherlands; Boston, MA, USA; London, UK, 1999; p. 238.

48. Batima, P.; Natsagdorj, L.; Gombluudev, P.; Erdenetsetseg, B. Observed climate change in Mongolia. Assess. Imp. Adapt. Clim. Chang. Work Paper 2005, 12, 1-25.

49. Biazrov, L.G.; Ganbold, E.; Gubanov, I.A.; Ulziikhutag, N. Flora of Khangaya; Nauka: Lenningrad, Russia, 1989; 191p. (In Russian) 